Florida International University

FIU Digital Commons

FIU Electronic Theses and Dissertations

University Graduate School

$10-21-2014$

\title{
Curriculum development in a heritage language community-based school: A Qualitative inquiry regarding a Brazilian-Portuguese program in South Florida
}

Ivian Destro Boruchowski

Florida International University College of Education, idestro@yahoo.com.br

DOI: $10.25148 /$ etd.FI14110712

Follow this and additional works at: https:// digitalcommons.fiu.edu/etd

Part of the Bilingual, Multilingual, and Multicultural Education Commons, Curriculum and $\underline{\text { Instruction Commons, and the Teacher Education and Professional Development Commons }}$

\section{Recommended Citation}

Boruchowski, Ivian Destro, "Curriculum development in a heritage language community-based school: A Qualitative inquiry regarding a Brazilian-Portuguese program in South Florida" (2014). FIU Electronic Theses and Dissertations. 1588.

https://digitalcommons.fiu.edu/etd/1588 


\section{FLORIDA INTERNATIONAL UNIVERSITY \\ Miami, Florida}

CURRICULUM DEVELOPMENT IN A HERITAGE LANGUAGE COMMUNITY-

BASED SCHOOL: A QUALITATIVE INQUIRY REGARDING A BRAZILIAN-

PORTUGUESE PROGRAM IN SOUTH FLORIDA

A thesis submitted in partial fulfillment

of the requirements for the degree of

MASTER OF SCIENCE

in

CURRICULUM AND INSTRUCTION

by

Ivian Destro Boruchowski

2014 
To: Dean Delia C. Garcia

College of Education

This thesis, written by Ivian Destro Boruchowski, and entitled Curriculum Development in a Heritage Language Community-based School: a Qualitative Inquiry Regarding a Brazilian-Portuguese Program in South Florida, having been approved in respect to style and intellectual content, is referred to you for judgment.

We have read this dissertation and recommend that it be approved.

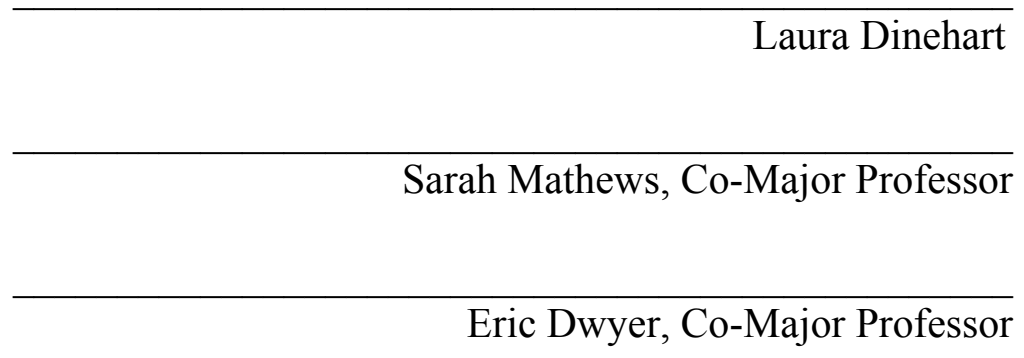

Date of the Defense: October 21, 2014

The dissertation of Ivian Destro Boruchowski is approved.

$\begin{array}{r}\begin{array}{r}\text { Dean Delia C. Garcia } \\ \text { College of Education }\end{array} \\ \hline \begin{array}{r}\text { Dean Lakshmi N. Reddi } \\ \text { University Graduate School }\end{array}\end{array}$

Florida International University, 2014 


\section{DEDICATION}

I dedicate this thesis to Luiz Fernando Boruchowski, my love and mate, who always supported me, and also helped me at the difficult times. I also dedicate this work to my sons, Heitor and Victor, who have been challenged me everyday to be a better person. They are the reason why I have being dedicated to the heritage language field. 


\section{ACKNOWLEDGMENTS}

I wish to thank the members of the committee for their support. Laura Dinehart for challenged me to study a real HL community-based school, what made a great difference in my learning path. To Sarah Mathews that helped me to understand multiculturalism and qualitative research. To Eric Dwyer, that from the beginning embraced my journey of being a researcher, for all the direct, accurate, and humorous guidance during my Master degree and the thesis process. Thank you all for the knowledge shared with me and for the time dedicated to helping me.

I want to thank all the Foundation Vamos Falar Português teachers and coordinators that participated from their heart in this study, especially Beatriz Carrielo, who opened the door of the school and kindly shared the knowledge accumulated with this experience over the time.

I also wish to thank Lori Ann Gionti from The Office of the Academic Writing and Publication Support, for helping me to improve my academic English language skills. 


\begin{abstract}
OF THE THESIS
CURRICULUM DEVELOPMENT IN A HERITAGE LANGUAGE COMMUNITYBASED SCHOOL: A QUALITATIVE INQUIRY REGARDING A BRAZILIANPORTUGUESE PROGRAM IN SOUTH FLORIDA
\end{abstract}

by

Ivian Destro Boruchowski

Florida International University, 2014

Miami, Florida

Professor Eric Dwyer, Co-Major Professor

Professor Sarah Mathews, Co-Major Professor

This research aimed to describe, understand, and discuss the curriculum development process of a Brazilian-Portuguese heritage language community-based school in South Florida.

This study was guided by the following research questions: (a) What roles does this HL community-based school aim to play for its students? This investigation was also related to the subsidiary question: (b) How does this HL community-based school organize its curriculum development process? In order to explore these research questions, I observed and interviewed teachers and coordinators based on a qualitative research approach.

I analyzed the interviews' transcripts, and the program's website with a central focus of describing and understanding their curriculum development process. Hopefully, the findings will help Brazilian and other HL community schools toward discussing and 
elaborating their own curriculum development, as well as to look for specific teacher training courses. 


\section{TABLE OF CONTENTS}

CHAPTER

PAGE

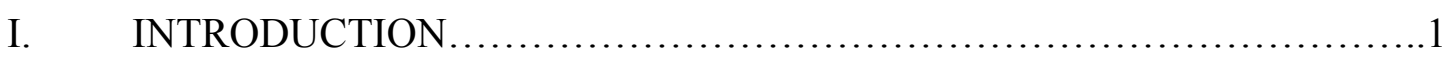

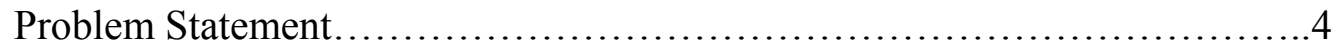

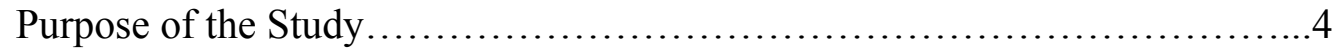

Research Questions...................................................

Rationale and Significance of the Study ..................................

Assumptions of the Study .................................................

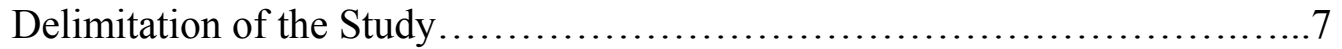

Chapter Summary .........................................................

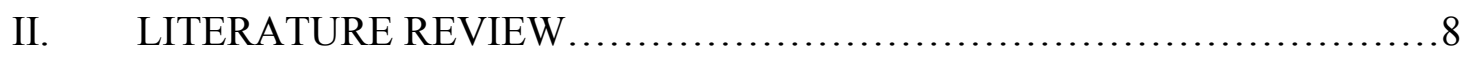

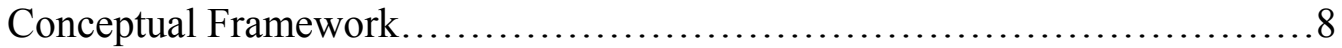

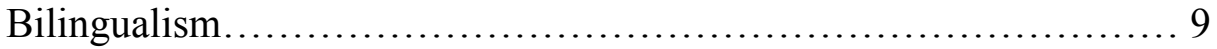

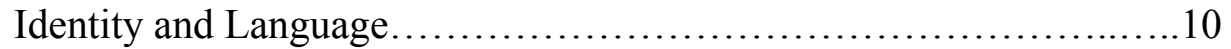

Heritage Language............................................... 11

Heritage Language Community-based Schools........................12

Curriculum..........................................................

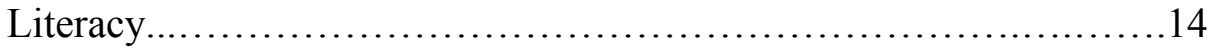

Further Discussion of the Concepts...................................... 16

Bilingual Education in the U.S.................................16

Bilingual Language Acquisition....................................20

Heritage Language Community-based Schools........................22

Heritage Language Learners Needs................................26

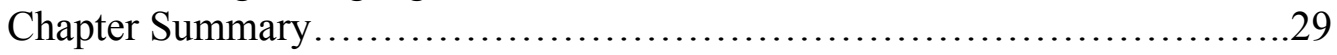

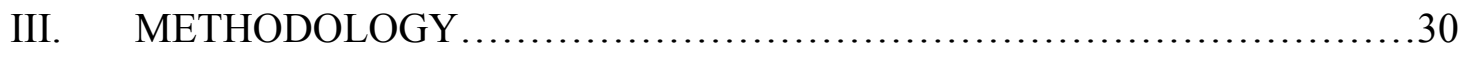

Research Questions................................................ 30

Research Design.........................................................

Population and Sample................................................. 31

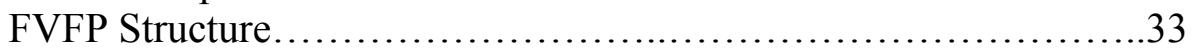

Physical Settings................................................ 33

Description of the Participants.......................................33

Data Collection......................................................... 34

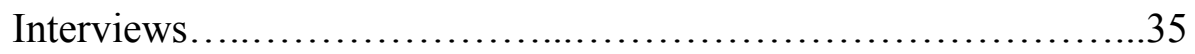

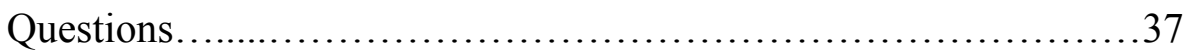

Ethical Considerations........................................... 40

Data Analysis......................................................... 41

Role of the Researcher................................................. 43

Delimitations of the Study and Validity .................................44

Chapter Summary ........................................................ 44 


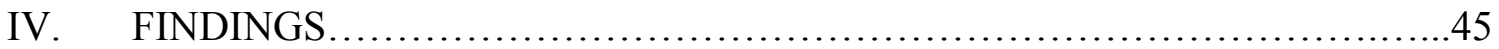

The HL Community-based School Researched.............................45

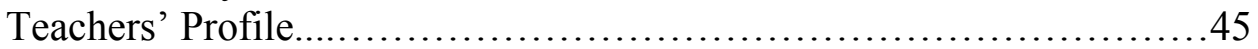

Coordinators' Profile.................................................46

Description of the Documents Examined..............................47

Findings Based on Research Questions.....................................47

What Roles does this HL Community-based School Aim to Play

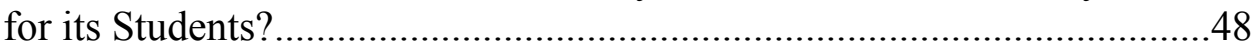

Coordinators and Teachers Discourse of the School Roles.................49

To develop linguistic and cultural belonging in an HL.................50

To maintain students' oral language abilities............................51

To enhance children's pride of speaking a language other than English at home.................................................53

To make parents aware of the family's crucial role in raising

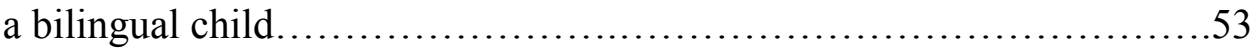

Comparison between the program's written general aims

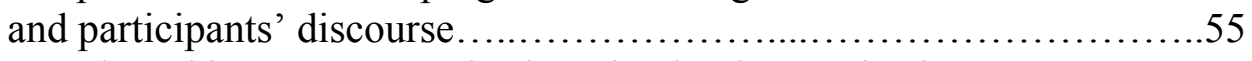

How does this HL Community-based School Organize its

Curriculum Development Process?.........................................................56

Fundamental concepts for heritage language education...................56

Participants' understanding about what a school is.......................57

Participants' perspectives about their teaching-learning

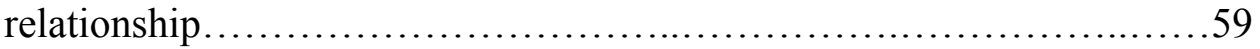

Participants' understanding of what bilingualism is.......................59

Participants' understanding of what literacy is............................60

Participants' understanding of what a language is and how languages

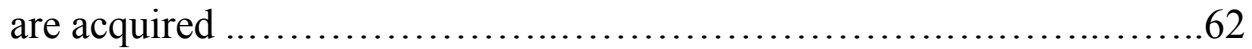

Curriculum Goals...............................................63

To maintain HLLs' oral language abilities.............................64

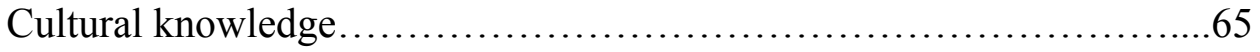

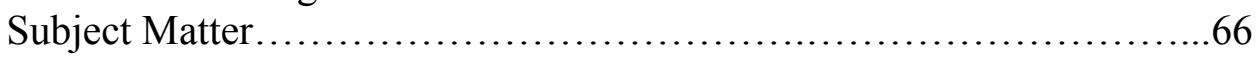

Curriculum Planning ..................................................

Instructional Strategies............................................ 70

Task-based instruction............................................. 72

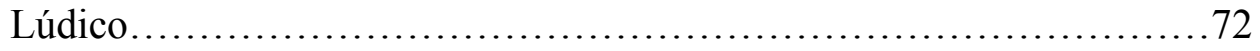

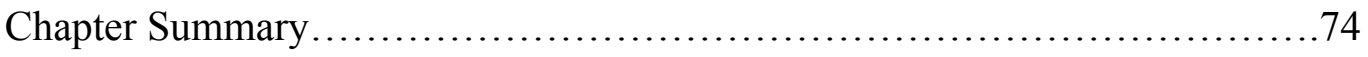




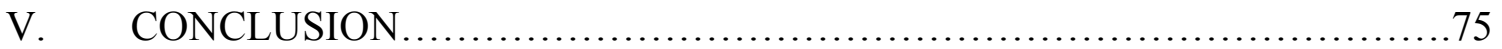

Roles of the HL Community-based School.................................. 75

Parental Engagement and Education..........................77

What does Maintaining Students' Languages Abilities Mean?.....79

Discussion of the School Curriculum.....................................80

Recommendations for a Curriculum Development Process........83

The fundamental concepts for HL education....................83

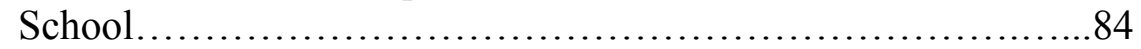

Bilingualism........................................... 85

Language................................................. 87

Literacy................................................. 88

The school curriculum goals.................................90

The instructional strategies..............................92

Conclusion......................................................93

LIST OF REFERENCES ...................................................96

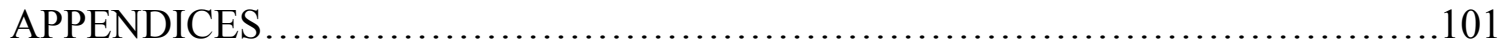




\section{CHAPTER I \\ INTRODUCTION}

Era uma vez...

Moving to a new country brings unexpected challenges. When I arrived in Miami

5 years ago, I had to face raising my sons without my family support or background knowledge of the new society. At that time, a difficult task - one that never occurred to me - emerged: If I do not make the effort myself, my sons will not learn Portuguese, they will not learn about Brazilian culture, they will not share their experiences with their grandparents, who do not speak English, and they will not learn from their experiences.

My desire, that of a mother, was to build heritage: that is, to share my culture, my values, and my language with my descendants. As an immigrant, I understood that this demand would take extra effort. I felt challenged by questions such as these: Will my sons feel attached to my family values? Will they understand my family culture? Will they feel estranged from their own family? Will I be able to teach a language and a culture if I only speak it a few hours a day with my sons? How will they maintain and develop a language and a culture when the school and the society do not use it or support it?

Sharing these questions with other parents, I realized that these concerns were similar to those of many immigrants. Usually, young immigrant children develop their family language, or their Heritage Language (HL), at home. However, when they start their regular schooling, they switch their language predominance to the language of the society (O'Grady, Kwak, Lee, \& Lee, 2011). Upon switching, often it becomes more 
difficult for children to share their experiences and thoughts with their extended family that only speak the minority language.

Sometimes, parents concerned with these issues start informal meetings such as play dates in an attempt to maintain and develop their children's HL and culture. Some initiatives become quite structured and organized with regular meetings on weekends or after-school hours in order to provide more language input, start literacy activities, and to share cultural knowledge (Lico, 2011). In the past, these initiatives were named ethnic schools (Fishman, 2001), but today, they are known as HL community-based schools (McInerny, 2013). Specifically, these programs conduct activities focused on developing children's abilities to read and write, as well promoting culture knowledge in their family language.

During my five years of living in the U.S., I have encountered a number of initiatives promoting Portuguese as an HL, including ABRACE in Washington; Brasil em Mente in New York; Movimento Educacionista in Massachusetts; Manhãs Brasileiras and Fundação Vamos Falar Português in Florida. This last one, Fundação Vamos Falar Português (FVFP) is a non-governmental, non-partisan, and non-profit organization, created with the mission of promoting Portuguese language and Brazilian cultural heritage among children and adolescents from the Brazilian community living in South Florida. The school offers Saturday morning classes and promotes weekend events in order to unite the Brazilian community in South Florida. 


\section{Problem Statement}

In 2013, the director of the Center for Applied Linguistics, Joy Peyton, observed that there are approximately 10,000 HL community-schools in the U.S., which teach 200 different languages (McInerny, 2013). Historically these types of programs are predominantly outside mainstream schooling and are organized as community projects.

Research, including You and Liu’s (2011) investigation on stakeholders' perspectives on Chinese and Korean schools in the U.S., has reinforced the important function of HL community schools as centers that act as major agents to prevent "language shift" and to promote language maintenance. Wong and Lopez (2000) observed that these schools also create a sense of cultural and ethnic pride, while providing an environment for children and parents to socialize with peers in their HL. However, researchers (such as Duff, 2008; Douglas, 2008) observed that these programs have many challenges. Usually, personnel implementing them do not have a professional background in education, nor do they have experience in curriculum development. Teachers also have difficulties accommodating a wide range of students in classes: there is a shortage of textbooks dedicated to this field (Duff, 2008) and these schools commonly experience insufficient funding (Douglas, 2008).

\section{Purpose of the Study}

As Rivera-Mills (2012) highlighted, there is a need to integrate the recent research into teacher training programs, material design, and curriculum planning for HL community schools. This research aimed to describe, understand, and discuss the 
curriculum development process of a community-based school in South Florida and make further recommendations that can be considered valid for other centers in the U.S.

\section{Research Questions}

This study is guided by the following research questions: (a) What roles does this HL community-based school aim to play for its students? This investigation additionally relied on the school workers' perspectives and was related to the subsidiary question: (b) How does this HL community-based school organize its curriculum development process? In order to explore these two research questions, I observed and interviewed HL community-based school teachers and coordinators and analyzed the interview transcripts, the program's website, and the notes that I took during the interviews, with a central focus on describing and understanding their curriculum development process.

\section{Rationale and Significance of the Study}

The HL field became an area of study for language maintenance and developmental purposes for many reasons, including the following: the democratic sense of a multicultural society, helping families preserve their heritage culture, and developing a great resource of bilingual speakers to work in a globalized world, and in special political and economic assignments (Peyton, Ranard, \& McGinnis, 2001).

In the HL field, much of the recent research has been dedicated to sociolinguistic knowledge about connecting language and identity (Potowski, 2012), language varieties (Valdés, 2001), and language motivation (Carreira and Kagan, 2011). However, some researchers including Rivera-Mills (2012) and Liu, Musica, Koscak, Vinogradova, and 
Lòpez (2011) observed that there is a need to integrate these findings into teacher training programs, material design, and curriculum planning.

Usually, HL community-based schools do not formalize their curriculum as a written document. Consequently, the significance of this study relied on describing and understanding how teachers and coordinators discuss and elaborate on their pedagogical experiences when they are selecting aims, methods, contents, and instructional strategies for their classes. The relevance of this research was related to the necessity for understanding and discussing HL community-schools and their pedagogical practices. The wider implication is to contribute to further recommendations in HL curriculum design considering the HL teachers' and students' specific needs. Findings from this study can contribute more specifically by

- Providing a basic HL curriculum development structure;

- Assisting school workers, community, parents, and students in discussing and designing both their aims and a philosophical curriculum framework that takes into account their school's specific contexts;

- Assisting community-schools in critically reflecting about their pedagogical practices; and

- Discussing relevant issues for any HL teacher training courses.

\section{Assumptions of the Study}

For the purposes of this study, I have assumed that (a) curriculum is a compilation of philosophical values, learning expectations, and pedagogical directions that determine the interactions among teacher, students, knowledge, and assessment; (b) teachers and 
coordinators discussed and planned their pedagogical practices based on common aims; and (c) participants volunteered to take part in the study and answered all the questions honestly.

\section{Delimitation of the Study}

This study is delimited by the geographic variable. I investigated one HL community-based school in South Florida, one that is a favorable scenario for HL speakers due to a large immigrant community.

\section{Chapter Summary}

This study was conducted because there is a need for investigating HL community-based schools pedagogical practices. This study was designed to analyze the curriculum development process of an HL program based on interviews, notes, and the program's website. The purpose of this investigation was to describe, and understand how teachers and coordinators discuss, and elaborate their pedagogical experiences.

In order to foster a better comprehension of the study, Chapter II is dedicated to discussing and critiquing of the existing literature about HL community-schools curricula, as well as the creation of a conceptual framework. These concepts served as the lenses that generated both the questions and the scheme for interpreting the research findings. 


\section{CHAPTER II}

\section{LITERATURE REVIEW}

This chapter is divided into two parts. First, a conceptual framework is described, indicating concepts that constitute the lenses through which the researcher generates the questions and interprets the findings (Merriam, 2009). In order to gain a deeper comprehension of the heritage language (HL) community-based schools' pedagogical practices, I relied on specific understanding of bilingualism, identity, language, heritage languages, community-schools, curriculum, and literacy. Next, the chapter presents a literature review, which includes a discussion and critique of the existing literature about bilingual language acquisition, HL community-schools' curriculum, and the heritage language learners' needs.

\section{Conceptual Framework}

Bilingualism is a common phenomenon in our society. It is present in practically every country in the world, in different social classes, and all age groups. Bilingualism is not rare, and a body of research has been dedicated to understanding its complexities. While considering early bilingual speakers in the context of minority families, I aimed to describe and understand how a Heritage Language (HL) community-based school curriculum is organized. Historically in the U.S., these schools help immigrant families maintain and develop literacy in their family language, as well develop cultural knowledge in order to keep family identity. 


\section{Bilingualism}

Bilingualism is a common phenomenon in our society, and an increasing number of researchers (Baker, 2001; Bialystok, 2007; Gathercole, 2002; Gathercole, 2007; Gathercole, and Thomas, 2009; Grosjean, 2010) have investigated to understand its complexities.

Traditionally, the idealized definition of a bilingual person is someone equally proficient in the two languages learned. In the context of this study, however, it is important to understand as a continuum and dynamic condition: when bilinguals will demonstrate strengths in different contexts and domains over the course of a lifetime. On account of this, this study relied on François Grosjean's (2010) definition of bilinguals as "those who use two or more languages (or dialects) in their everyday lives" (Grosjean, 2010, p. 4). The appropriateness of selecting this explanation lies in the use and not the fluency as a criterion to define bilinguals, thus embracing Heritage Language Learners' (HLLs) linguistic and cultural abilities, despite their lesser fluency in different contexts and domains.

In an effort to understand bilingualism, Colin Baker (2001) considered the abilities of speaking and writing as productive competencies, and understanding and reading as receptive competencies. Baker also highlighted one aspect related to the language use: the domain. The domain refers to the social context where the language is acquired and used, such as in familial, school, or street settings (Baker, 2001). 


\section{Identity and Language}

In the context of minority students in United States, Sonia Nieto (2002) observed a predominant ideology of the "either/or" belonging, and an implicit idea that, to participate in U.S. society, HLLs would abandon a family culture, identity, and language (p. 103). However, Hall and Gay (1996) discussed identity and how it is compiled as points of temporary attachment by one's representation of the junction between discourses and practices. In the HL field, Kim Potowski (2012) also observed that an important construct in identity theory is the fact that it can often involve ambivalence, not necessarily seeing a contradiction between an ethnic identity and an U.S. identity, thus creating a hybrid identity.

This research inferred that identity categories are not fixed; they are negotiated from combinations that change over the time. This study relied on a multifaceted and fluid concept of identity to understand how HLLs view themselves and relate to an HL, as well as the language of the society. Based on these ideas, I assumed that minority language students can belong to multiple cultures and create multiple identity discourses. Furthermore, I valued the development of a multicultural identity based on LaFromboise, Coleman, and Gerton (1993) claim that ethnic minorities who develop bicultural competence will have higher self-concept, self-esteem, and confidence.

Since it is through recurrent use of conventionalized forms of language that individuals develop relationships, establish communities, and get things done (Hyland, 2002), consequently language and identity are considered integrated and fundamental notions of social realities. Investigating Korean HLLs, Lee and Kim (2008) observed that for these learners the language does not simply perform the function of ordinary 
communication, but it is also a symbolic marker of identity. He (2008) further suggested that, for HLLs, language is constructive of an identity because it is "structured in the everyday flow of language, and stabilized in the pragmatic narratives of our day-to-day, fluid social life" (He, 2008, p. 4).

\section{Heritage Language}

Despite the Native American languages and the long history of immigration in this country, any language other than English is usually referred to as foreign. However, these languages are not strange to many individuals as they bind identities, families, and communities (Kelleher, 2010).

$\mathrm{HL}$ is established as a language used with restrictions, such as in a community and in a family setting, and coexisting with other languages that are broadly used in the society, media, and institutions. HL acquisition is characterized by unusual exposition patterns, and, in a typical situation, the input is ample in the first years of the child's life; however, it ends or has a dramatic reduction after the child enters school ( $\mathrm{O}^{\prime} \mathrm{Grady}$, Kwak, Lee \& Lee, 2011).

Some researchers have debated the term "heritage" because it becomes associated with ancient cultures, and past traditions, thereby failing to represent a modern and international language in a contemporary society. Terrence Wiley (2001) observed that it is important to comprehend the elasticity of this term and account for the sociolinguistic context of the language speakers and the language use.

Maintenance and development of HL abilities is a concern for families, researchers, educators, and policy makers for many reasons: the democratic sense of a 
multicultural society; helping to keep families attached; preserving heritage culture; developing a great resource of bilingual speakers to work in a globalized world, and in special and economical assignments (Peyton, Ranard, \& McGinnis, 2001); and, as research in the field of linguistic has shown, improving learners' abilities in their second language, in this case, English (Gathercole, 2002).

In the United States, for reasons of "homeland security" (McGinnis, 2005), there is even more interest in maintaining and developing HLLs' abilities in order to raise bilingual citizens who can help translating documents and work in diplomatic missions. In recent years, the field has raised interest among applied linguists and educators, who have become advocates for HL education (Li and Duff, 2008).

\section{Heritage language Community-based Schools}

Historically HL community-based schools are predominantly outside mainstream schooling. The activities vary in population served, program structure, material used, and staff qualifications (Kelleher, 2010).

Joshua Fishman (2001) researched community-based schools in the U.S., first between 1960-1963 when he located 1,885 ethnic schools, and then 20 years later, when he identified 6,553 programs. However, he commented that there were 1,000 more centers that he could not access at that time. He also accounted for 145 different languages taught, and highlighted that usually foreign governments, religious institutions, and communities support these centers. In the 2013 UCLA International Heritage Language Conference, Joy Peyton, director of the Center for Applied Linguistics, 
commented that today there are approximately 10,000 HL community-schools throughout the U.S. offering nearly 200 different languages (McInerny, 2013).

Compton (2010) remarked that classes may be open from preschoolers to seniors;

consequently, students vary in age, background, and interest. The staff consists of administrators, teachers, interns, parents, and other community members that sometimes receive a salary and sometimes work on a voluntary basis. Today, some HL communityschools partner with local public school or community colleges.

\section{Curriculum}

This study perceives curriculum as a compilation of philosophical values, learning expectations, and pedagogical directions that determine the interactions among teacher, students, knowledge, and assessment. Curriculum begins as a theoretical discussion that will drive methodological choices, content selections, class preparation, and the dynamic between students-teacher interactions. The curriculum must materialize when teachers, students, and knowledge are interacting during the activities as well as in the materials that they produce. As Peter Oliva (2009) observed, the purpose of a curriculum is to provide a vehicle for ordering and directing the experiences at school.

Curriculum development then may be understood "as the process for making programmatic decisions and for revising the products of those decisions on the basis of continuous and subsequent evaluation" (Oliva, 2009, p. 127). According to this perspective, curriculum development is a decision-making process and a never-ending process, with three phases: planning, implementation, and evaluation. 
Curriculum planning is the preliminary phase of curriculum development, when the school community thinks, makes decisions, and takes actions to establish what teachers and students will carry out. This stage is based on points of integration between schools workers and community viewpoints about society, education, literacy, instruction, disciplines, contents, emphasis, etc. Curriculum implementation is the conversion of the established goals in instruction. During implementation, methods, strategies and interaction among teachers, students, and knowledge are defined. Finally, curriculum evaluation is the process of making changes in the existing curriculum in order to improve it (Oliva, 2009).

This study also relied on Posner's (2004) ideas that schools have five concurrent curricula. The official curriculum is the written document that gives the teachers a basis for planning lessons and evaluating students, as well as for administrators a basis for supervising teachers. The operational curriculum consists of what is actually taught and it is compound of two aspects: the content, and the learning outcomes. The hidden curriculum is the set of norms and values that a school embodies. The null curriculum consists of what is not selected to be taught. The extra curriculum comprises the learning experiences outside the school.

\section{Literacy}

Newman (2006) presented two families of literacy concepts: on one hand, literacy is viewed as a text to decode; on the other, however, literacy is positioned in the social contexts where this skill is learned and used. This study relied on this last perspective about literacy development. When literacy is positioned in social contexts, the approach 
is named "social literacy" and "New Literacy Studies" (Newman, 2006). According to these studies, literacy is not only the ability to encode and decode written language per se, but also the knowledge of a practice, that is, the ability to use it in specific contexts. As a consequence, someone can be considered literate in one context, but not in another. The target of the literacy process is to build writers and readers who become part of the communities where each has its own rules, conventions, and cultures of literacy (Hyland, 2002). Consequently, literacy is related to understand genres rules. Based on Hyland's (2002) observations, genres:

are abstract, socially recognized ways of using language. Genre analysis is based on two central assumptions: that the features of a similar group of texts depend on the social context of their creation and use, and that those features can be described in a way that relates a text to others like it and to the choices and constraints acting on text producers. Language is seen as embedded in (and constitutive of) social realities, since it is through recurrent use and typification of conventionalized forms that individuals develop relationships, establish communities, and get things done. So genre theorists locate participant relationships at the heart of language use and assume that every successful text will display the writer's awareness of its context and the readers, which form parte of that context. (p. 114)

Anchored in the sociological perspective, this study understands literacy as not only the ability to decode and encode the written language, but also a capability to read 
and write in the context of our complex society (Ferreiro, 2010). And in order to fully participate in different communities, students must have the capability to understand the social context of the genres to which they are exposed.

\section{Further Discussion of Concepts}

The HL field became an area of study for language maintenance and

developmental purposes for many reasons. These reasons include creating a democratic sense of a multicultural society, keeping families attached and preserving their heritage culture, and developing a great resource of bilingual speakers (Peyton, Ranard, \& McGinnis, 2001). This section discusses and critiques existing literature about bilingual education in the U.S., bilingual language acquisition, HL community-based schools curriculum, and HLLs' needs.

\section{Bilingual Education in the U.S.}

Despite the long history of immigration in the United States there is no official consensus on the value and meaning of bilingualism. Bilingual education in this country has a long and complex history, playing various roles in different periods. Related to students from immigrant families, there is an umbrella of bilingual education types and aims, from fostering bilingualism for a specific time seeking that they be assimilated in the majority language, to initiatives for maintaining and developing biliteracy.

Considering the intrinsic limitations of typologies, Colin Baker (2011) organized the 10 most common types of programs dedicated to bilingual children separating them in three 
types: first, the programs that aim to achieve monolingualism; then two types of bilingual education, the weaker (see Table 1) and the stronger programs (see Table 2).

Table 1

Weak Forms of Bilingual Education for Bilinguals

\begin{tabular}{|c|c|c|c|c|}
\hline $\begin{array}{l}\text { Type of } \\
\text { program }\end{array}$ & $\begin{array}{l}\text { Typical } \\
\text { type of } \\
\text { child }\end{array}$ & $\begin{array}{l}\text { Language } \\
\text { of the } \\
\text { classroom }\end{array}$ & $\begin{array}{l}\text { Societal and } \\
\text { educational aim }\end{array}$ & $\begin{array}{l}\text { Aim in } \\
\text { language } \\
\text { outcome }\end{array}$ \\
\hline Transitional & $\begin{array}{l}\text { Language } \\
\text { minority }\end{array}$ & $\begin{array}{l}\text { Moves } \\
\text { from } \\
\text { minority to } \\
\text { majority } \\
\text { Language }\end{array}$ & Assimilation/subtractive & $\begin{array}{l}\text { Relative } \\
\text { monolingualism }\end{array}$ \\
\hline $\begin{array}{l}\text { Mainstream } \\
\text { with FL }\end{array}$ & $\begin{array}{l}\text { Language } \\
\text { majority }\end{array}$ & $\begin{array}{l}\text { Majority } \\
\text { Language } \\
\text { with L2/FL } \\
\text { lessons }\end{array}$ & Limited enrichment & $\begin{array}{l}\text { Limited } \\
\text { bilingualism }\end{array}$ \\
\hline Separatist & $\begin{array}{l}\text { Language } \\
\text { minority }\end{array}$ & $\begin{array}{l}\text { Minority } \\
\text { Language }\end{array}$ & Detached/autonomy & $\begin{array}{l}\text { Limited } \\
\text { bilingualism }\end{array}$ \\
\hline
\end{tabular}

Table 2

Strong Forms of Bilingual Education for Bilingualism and Biliteracy

\begin{tabular}{|c|c|c|c|c|}
\hline $\begin{array}{l}\text { Type of } \\
\text { program }\end{array}$ & $\begin{array}{l}\text { typical type } \\
\text { of child }\end{array}$ & $\begin{array}{l}\text { Language of } \\
\text { the classroom }\end{array}$ & $\begin{array}{l}\text { Societal and } \\
\text { educational } \\
\text { aim }\end{array}$ & $\begin{array}{l}\text { Aim in language } \\
\text { outcome }\end{array}$ \\
\hline Immersion & $\begin{array}{l}\text { Language } \\
\text { majority }\end{array}$ & $\begin{array}{l}\text { Bilingual with } \\
\text { emphasis on } \\
\text { L2 }\end{array}$ & $\begin{array}{l}\text { Pluralism and } \\
\text { additive }\end{array}$ & $\begin{array}{l}\text { Bilingualism and } \\
\text { biliteracy }\end{array}$ \\
\hline $\begin{array}{l}\text { Maintenance/ } \\
\text { HL }\end{array}$ & $\begin{array}{l}\text { Language } \\
\text { minority }\end{array}$ & $\begin{array}{l}\text { Bilingualism } \\
\text { with emphasis } \\
\text { on L1 }\end{array}$ & $\begin{array}{l}\text { Maintenance, } \\
\text { pluralism, and } \\
\text { additive }\end{array}$ & $\begin{array}{l}\text { Bilingualism and } \\
\text { biliteracy }\end{array}$ \\
\hline $\begin{array}{l}\text { Two-way/ } \\
\text { Dual } \\
\text { language }\end{array}$ & $\begin{array}{l}\text { Mixed } \\
\text { Language } \\
\text { minority \& } \\
\text { majority }\end{array}$ & $\begin{array}{l}\text { Minority and } \\
\text { majority }\end{array}$ & $\begin{array}{l}\text { Maintenance, } \\
\text { pluralism, and } \\
\text { additive }\end{array}$ & $\begin{array}{l}\text { Bilingualism and } \\
\text { biliteracy }\end{array}$ \\
\hline
\end{tabular}




\begin{tabular}{llll}
$\begin{array}{l}\text { Mainstream } \\
\text { bilingual }\end{array}$ & $\begin{array}{l}\text { Language } \\
\text { majority }\end{array}$ & $\begin{array}{l}\text { Two majority } \\
\text { Language } \\
\text { Pluralism }\end{array}$ & $\begin{array}{l}\text { Maintenance, Bilingualism } \\
\text { pluralism, and } \\
\text { additive }\end{array}$ \\
\hline
\end{tabular}

Note. Adapted from “A typology of bilingual education”, by C. Baker (2011).

Foundations of bilingual education and bilingualism. p. 209-210.

Baker (2011) posited that there are usually two main options for minority students

to develop biliteracy: (a) bilingual education offered in mainstream schools; (b) minority

HL community-based schools. Considering the effectiveness of the programs in the

mainstream schools, Thomas and Collier (2002) concluded that the optimal program for a

long-term academic success of language minority students is the two-way bilingual

education, also named as dual language bilingual schools. This program was created in

1963 in Dade County, Florida, in order to teach Spanish and English to the U.S. Cuban

community students. Researchers observed that these programs are the most effective

course toward achieving biliteracy and higher academic skills in both languages taught

(Thomas and Collier, 2002). Despite the research showing the effectiveness of these

programs, only 363 schools offered them in the U.S. in 2010 (Baker, 2011).

In the school system, HL students are currently classified as English Language

Learners (ELLs) to be served with assistance language programs. However, schools do not typically accommodate the need of this population to develop full biliteracy.

Additionally, when mainstream schools offer languages other than English, these HL

students are usually incorporated in foreign language courses, which do not address their specific needs (Kelleher, 2010).

Taking into account the HLLs' previous language proficiency and sociocultural experiences, Kagan and Dillon (2002) compared the pedagogical needs between typical HLLs and foreign language students. As can be observed in the following table, HLLs 
have unique needs that community-based schools should discuss and pay attention to organize their curriculum development process and design materials.

Table 3

Non-heritage and HLLs pedagogical needs

\begin{tabular}{|c|c|c|}
\hline Teaching domains & Non-heritage learners & Heritage learners \\
\hline $\begin{array}{l}\text { Pronunciation and } \\
\text { intonation }\end{array}$ & $\begin{array}{l}\text { Instruction throughout the } \\
\text { course }\end{array}$ & Typically none \\
\hline Vocabulary & Full range & $\begin{array}{l}\text { Age appropriate/ literary/ } \\
\text { academic/ formal }\end{array}$ \\
\hline Grammar & $\begin{array}{l}\text { Micro-approach (case by } \\
\text { case) }\end{array}$ & $\begin{array}{l}\text { Macro-approach (by } \\
\text { concept) }\end{array}$ \\
\hline Reading & $\begin{array}{l}\text { Small texts, gradually and } \\
\text { slowly increasing in volume } \\
\text { and complexity. }\end{array}$ & $\begin{array}{l}\text { Fairly large and complex } \\
\text { text almost from the } \\
\text { beginning. }\end{array}$ \\
\hline Writing & $\begin{array}{l}\text { Sentence level, gradually } \\
\text { advancing to paragraph } \\
\text { level. }\end{array}$ & $\begin{array}{l}\text { High degree of internal } \\
\text { grammar allows expansive } \\
\text { writing assignments at early } \\
\text { stages. Macro-approach to } \\
\text { writing: concentrate on the } \\
\text { content and gradually } \\
\text { improve spelling, grammar, } \\
\text { and stylistics. }\end{array}$ \\
\hline Speaking & $\begin{array}{l}\text { Micro-approach: initially } \\
\text { restricted to dialogues, } \\
\text { gradually progressing to } \\
\text { monologue and discussion. }\end{array}$ & $\begin{array}{l}\text { Macro-approach: emphasis } \\
\text { on monologue and } \\
\text { discussion }\end{array}$ \\
\hline Listening & $\begin{array}{l}\text { Micro-approach: short } \\
\text { simple texts, gradually } \\
\text { increasing in volume and } \\
\text { complexity. }\end{array}$ & $\begin{array}{l}\text { Macro-approach: full range } \\
\text { of native language input } \\
\text { (movies, documentaries, } \\
\text { lectures). }\end{array}$ \\
\hline Culture & $\begin{array}{l}\text { Micro-approach: initially } \\
\text { isolated cultural items }\end{array}$ & $\begin{array}{l}\text { Macro-approach: full range } \\
\text { of native language and } \\
\text { culture input (audio, visual, } \\
\text { and print). }\end{array}$ \\
\hline
\end{tabular}

Note: Adapted from Kagan and Dillon, 2002, p.6-7. 
As observed, the oral language previous skills, some local sociocultural experiences, and the issues related to multiple identities differentiate HLLs from foreign language learners. This characteristics drive to a specific curriculum discussion for HLLs.

\section{Bilingual Language Acquisition}

Language development in monolingual and bilingual children takes place through a complex process of storing what they hear, abstracting form and patterns, and building structures to apply these patterns (Gathercole, 2007). Driven by a constructivist account of language development, Gathercole observed a typical process of bilingual language acquisition with five principles underlying language development:

- $\quad$ piecemeal acquisition, when children learn isolated forms;

- acquisition in context, when children associate these forms with the context in which they heard them;

- emergence of structure from accumulated knowledge, when children abstract patterns and concepts from different contexts;

- influence of language being learned on timing of acquisition relative to other developments, which means that the specific structure being learned plays a important role on future structures; and,

- the amount of exposure, which affects timing of development (Gathercole, 2007, pp. 5-6).

This last principle asserted the role of input related to a critical mass amount of data before a child discovers a general language pattern (Gathercole, 2002). In linguistics, 
the idea that monolingual and bilingual children's language development are to some extent influenced by the amount and frequency and quality of input which to they are exposed has been discussed at length and from many different theoretical points of view (Gathercole, 2007). Based on this observation, Paradis, Nicoladis, Crago, and Genesee (2010) indicated that the differences in the time of acquisition of complex structures between monolinguals and bilinguals can be explained. For bilinguals, the acquisition of simple structures seems to occur at the same time as for monolinguals; however, for complex structures there is a delay in bilinguals, which they attribute to a lack of a "critical mass" of input.

Considering that an early bilingual child is hearing input from different languages, in different contexts, Gathercole concluded that it "takes the bilingual child a little longer to develop those structures because of the need for the accumulation of enough data in order to draw out the relevant abstractions from the raw data supplied in the input" (Gathercole, 2007, p. 17). Frequency of input is determined by a complex interaction of factors such as the language spoken at home, the language of the school, and the socioeconomic status of the child. Research in linguistics has concluded that as children gain sufficient exposure to the structures of the minority language to draw out the necessary generalizations, the gap between bilinguals and monolinguals diminish or extinguish over time (Gathercole, 2002; Gathercole, 2007; Gathercole \& Thomas, 2009, Paradis, 2010).

The importance of quantity and quality of input in early bilinguals led us to consider how socio-cultural context influences these children's language development. Guathercole (2002) compared similarities and differences in bilingual development of two distant communities: Spanish speakers in Miami, and Welsh speakers in North 
Wales. The Spanish speakers in Miami pursued a status of immigrant population, while Welsh speakers had a native status. She concluded that the quality of input, related to the contact with fluent speakers, and the status of the minority language in the community play a critical role in bilingual language acquisition (Gathercole, 2002).

Paradis noted that for early bilinguals "input quality might be an equal, or perhaps more relevant, factor" (Paradis, 2011, p. 668). The researcher defined as input quality the differences in exposure; proficiency of interlocutors; and complexity of contact experienced via media, playmates, and organized extra-curricular activities.

Moreover, observing that HLLs in the United States usually experience a dramatic reduction in quality and quantity of input when they start school, researchers in Chinese communities have confirmed that HL community-based schools play an important role in learners' language maintenance. You and Liu (2011) noted that for parents and teachers these schools act as major agents that prevent "language shift" and promote language maintenance. The research suggests that parents, teachers and directors believe that sending their children to HL schools was one of the most effective way to help their children to maintain the HL.

Research has confirmed the positive effect of a strong first language development as a predictor of how well one acquires a second language. The number of years of instruction in the child's first language is a key predictor of how quickly the child will advance academically in school in her second language (Gathercole, 2007; Garthercole \& Thomas, 2009; Paradis, 2010). Considering these observations, we understand that community-based schools can play a critical role for HLLs to expand learners' minority language abilities as well as their abilities as English learners. 


\section{Heritage Language Community-based Schools}

Some researchers (e.g., Fishman, 2001) discussed how language maintenance depends on transmission across generations. Researchers agree that it is important to participate in a large-scale community on various levels to use different language domains (Rivera-Mills, 2012). The role of this "speech community" is to create an environment in which the HL can be reached and used beyond the family and the classroom domains and repertories. Consequently, the maintenance and development of an HL is related to efforts and participation from family, community-schools, and the community (Santa Ana and Parodi, 1998).

Historically, the HL community-based schools were committed to maintaining and developing minority language and culture. Fishman (2001) argued that these programs are vital for preservation of the languages in the U.S. Some researchers, including Wong \& Lopez (2000), concluded that the most important function of these centers is to create a sense of cultural and ethnic pride, while providing an environment for children and parents to socialize with peers in their HL. As observed before, recent research has pointed out that the HL community-based schools also have an important role in preventing language shift (You and Liu, 2011; Shibata, 2000).

Recently, García, Zakharia, and Otcu (2013) researched schools in New York and observed a new perspective in the HL community-schools' programs:

These programs demonstrate a complexity that is not fully captured by seeing them simply as "heritage language" programs. These cases also show a 
commitment to bilingualism that goes beyond the timid US conception of "bilingual education". The educational spaces presented here focus not solely on teaching a "heritage" language, a language of the past, but on living these languages practices in the present, and providing students with life experiences and performances that will enable them to practice their bilingualism in a future global world. The goal of these bilingual community education programs in the present is not simply the maintenance of an ethnic-mother tongue, as Fishman would have said, or the development of a heritage language, as heritage languages proponents would claim. The goal of these bilingual community education programs is the bilingual development of American children living in a global multilingual context (pp. 10-11).

At the HL community-schools researched, Garcia et al. (2013) observed teachers and students negotiating plural language practices within English. A principal objective of these programs is for children to understand their place in a multilingual and transnational world, using plural interactions with English in a complex dynamic society. This idea of integration between the HL and social language was also observed at Chinese HL community-based schools (Lu, 2010). Garcia et al. (2013) also observed that these programs do not solely teach language. Their practices involve music, theater, arts, religion, hair braiding, tutoring in academic subjects, and many other cultural activities. Further research is needed to understand these new characters of community-based schools and how they are articulated with their curriculum development and instruction process. 
As observed before, HL community-based schools have many challenges. Usually personnel implementing these programs do not have a professional background in education; they rarely discuss any pedagogical project that might guide them toward preparing teacher instruction, material and curriculum development; they have difficulties accommodating students in multi-level classes; and, there is a lack of textbooks dedicated to this field (Duff, 2008). These schools also commonly experience insufficient funding, inadequacy of teaching methodology, and lack of well-qualified teachers (Douglas, 2008).

Compton (2010) observed that they are also challenged in raising public awareness. She understands that strengthening the quality of these centers is crucial because they are the widest range of language learning opportunity available in urban areas. As a strategy for improving instruction quality and funding, some schools articulate with other groups and institutions, while seeking support from governments abroad and institutions. In some areas of the United States, college and university students are working together with local heritage communities to include HL classes at regular schools, while awarding credit for language study at community-based schools when they meet district and state curriculum standards.

Some language groups have access to a range of materials for their students, and other groups lack basic textbooks for literacy. Sometimes it takes an international effort for these communities to produce or bring materials to the U.S. The uneven pedagogical development of the different language communities makes proposing a curriculum development process difficult. In addition, because the linguistic characteristics of HLLs 
differ from foreign language students and native speakers, strategies and instruments for assessing their skills are still in developmental stages.

\section{Heritage Language Learners Needs}

Recently, Hornberger and Wang (2009) adopted a wider definition of HLLs: "individuals who have familial or ancestral ties to a particular language that is not English and who exert their agency in determining whether or not they are HLLs" (p. 27). However, this study relied on Guadalupe Valdés's (2001) definition of HLLs as individuals with a historical or personal connection to a family language, which they speak or merely understand, and are bilinguals to some degree (Valdés, 2001). For educational purposes, Valdés's definition offered an important differentiation from learners who can at least understand the HL to participate at community-based school classes that mainly use the HL in their activities.

Researchers have discussed how teachers should not mistakenly assume that all HLLs bring to classes immense advantages if compared with a foreign language speakers. Lynch (2003) and Valdés (1995) observed that in reality, HLLs have shown different ranges of language competence, from merely being a member of a receptive audience to becoming a balanced user of the two languages systems to which they have been exposed. Parodi (2009) described that U.S. Spanish HLLs who visit Latin American countries have experienced negative attitudes towards their choice vocabulary, slow pace of speaking, and grammatical mistakes. It is common that HL competence refers to the casual and conversational speech register used with familiar interlocutors and restricted to a set of topics focused on everyday life (Valdés, 1995). 
For some researchers (e.g.,Valdés, 1995, and Parodi, 2009) HLLs' literacy is considered a key issue, and HL community-schools' curriculum should be designed to expand the functional domain of the family language register, including the oral and written standard registers of the target language. In this study, register was understood as a particular use of the language in a particular social setting that varies from more formal to more informal purposes.

To be capable of using the standard register of a language is considered important because it gives students' expression more validity in the places where this type of the language is used. In our society, certain ways of communication have more credibility than others. This research valued a critical literacy approach, which discusses the standard language register as an artificial form of the language adopted by some specific institutions such as government, schools, and others. In other words, the use of the language is not neutral: it is also rather a powerful instrument used to be believed, obeyed, respected, and distinguished, as Pierre Bourdieu (2005) observed. HL teachers, therefore, need to discuss registers and dominance, as well as what should be linguistically efficient in different situations.

In the history of Spanish as a HL field, the first efforts of the programs were to substitute the non-standard registers, thereby devaluing students' home registers. Valdés (1995) and other researchers found such practice problematic and, as a result, they advocated for these programs to focus on the expansion of students' linguistics repertories, including prestige registers, without undermining their family's registers.

Valdés (1997) indicated that HL courses should incorporate reading skills, competence and creativeness in oral and written communication in order to increase the 
heritage learners' background. Colombi and Roca (2003) described that teachers that explicitly approach how language registers functions in different social contexts, help HLLs become more aware of appropriate lexical-grammatical features making their writing more effective.

Researching Portuguese HLLs, Silva (2010) also observed in her experience that is appropriate to recognize what language register the student brings to teach a course that aims toward bidialectalism, which entails not dismissing or correcting the students' family language, but incorporating other varieties of the language.

Regarding HLLs' teaching-learning interactions, this research considered Ruddel and Unrau (1994) theoretical reading model in order to develop students' literacy skills. For these authors, the driving force behind language performance is the readers' need to obtain meaning. During classes, meaning is a complex and dynamic result of all the interactions among texts, teachers, readers, classroom context, and sociocultural context. Ruddel and Unrau also extended the meaning process beyond printed manuscripts - to events, speech, and behaviors - as readers can interpret gestures, images, symbols, signs and signals embedded in a social and cultural environment. Regarding sociocultural context, Ruddel and Unrau (1994) also accounted for teachers and student prior beliefs, background knowledge, and the interpretation of the social life and culture as components in the meaning making process.

As a result, literacy must be related to social practices and cultures, and children need to be active participants in their own language and literacy development. This research understands that literacy teachers can have a critical role in mediating children's construction of their own experience with texts. However, further research is needed to 
understand how HL community-schools approach literacy and the roles that teachers are playing for the students in these settings.

\section{Chapter Summary}

This chapter presented and discussed concepts such as bilingualism, identity, language, heritage languages, community-based schools, curriculum, and literacy. These ideas organized a background theory to discuss HLLs' needs, as well as to frame how the researcher conducted the interpretation of the research questions about the communitybased school roles and its curriculum development process. 


\section{CHAPTER III \\ METHODOLOGY}

This chapter describes the methodology employed in answering the research questions. It delineates the research design, the population and sampling procedures, the gathering data process, and the researcher's role. Additionally, the chapter discusses the process of data analysis and interpretation, and its consequent trustworthiness.

\section{Research Questions}

The main research question for this study is (a) What roles does this HL community-based school aim to play for its students? This investigation relies on the school workers' perspectives and is related to the subsidiary question: (b) How does this HL community-based school organize its curriculum development process?

\section{Research Design}

In order to answer these questions, I observed and interviewed two teachers and three coordinators from a Brazilian-Portuguese HL community-based school in South Florida. A qualitative research approach was selected in order to describe and understand subjects' experiences when selecting aims, methods, contents, and instructional strategies. As Merriam (2009) observed, the overall purposes of qualitative research are to achieve the understanding of how people interpret their experiences, how they construct their worlds, and what meaning they attribute to their experience. This 
investigation relied on the school workers' perspectives in that HL community-based schools rarely formalize their curriculum as a written document (Merriam, 2009).

This investigation was developed as a qualitative case study dedicated to describing and analyzing a unit system, such as the selected HL community-based school. Despite the particularities and singularities of a case study as a bounded system, this type of investigation may help us understand a real-life phenomenon, illuminate meanings, and create hypotheses to help structure future research (Merriam, 2009). This investigation was undertaken with the expectation that the school workers' descriptions can contribute further recommendations in future curriculum design when professionals are considering the HL students' specific needs.

\section{Population and Sample}

In a United States Census Bureau (2010) report $19.7 \%$ of the U.S. population consisted of speakers of other language than English at home in 2007. As previously asserted, maintenance and development of language abilities of this population is a concern for families, researchers, educators, and policy makers for many reasons: the democratic sense of a multicultural society; keeping families attached to and preserving their heritage culture; and developing a great resource of bilingual speakers to work in a globalized world, and in special political and economic assignments (Peyton, Ranard, \& McGinnis, 2001). Furthermore, as research in the field of linguistic has shown, literacy skills in a primary language improves learners' ability in their second language, in this case, English (Gathercole, 2002). 
According to the United States Census Bureau there were 673,566 people aged 5 or older who spoke Portuguese or Portuguese Creole at home in 2010 (U.S. Census Bureau, 2013). However, these data may not paint a true picture of the Portuguesespeaking communities in the U.S. This report is based on the American Community Survey, which samples a small percentage of the population every year. In 2010, the Brazilian Ministry of Foreign Relationship estimated there were 1,388,000 Brazilians living in the U.S., and 300,000 of them in Florida (Brasil, Ministério das Relações Exteriores, 2011). One concern of this population is the maintenance and development of Portuguese HL abilities.

Among some initiatives promoting Brazilian-Portuguese as a HL is the Fundação Vamos Falar Português in Florida. This program is considered the first HL communityschool dedicated to the Brazilian variant of Portuguese in the U.S. Consequently, this program became a reference for other Brazilian communities and accumulated pedagogical experience that can contribute to others. Considering the richness of the information as a criterion, I selected the Fundação Vamos Falar Português (FVFP) as a purposeful sample from "which the most can be learned" (Merriam, 2009, p. 77).

The FVFP is a non-governmental, non-partisan, and non-profit organization created in 2004 by Brazilian community members in South Florida. The communitybased school was created with the mission of promoting the Portuguese language and Brazilian cultural heritage between children and adolescents from Brazilian families. During the first years, the organization promoted Brazilian-Portuguese language and cultural activities for HLLs on teacher's planning days in a Miami-Dade Library. In 
2007, the directors decided to make their activities more systematic and organized 1-hour activities per week.

\section{FVFP Structure}

When this study was conducted, the program's structure consisted of 10 directors; 3 general coordinators, one dedicated to pedagogical issues, one dedicated to funding, and one dedicated to communication; 6 unit coordinators; 9 teachers; 25 classes; approximately 300 students; and 10 volunteers who help teachers and unit coordinators.

\section{Physical Settings}

As observed by Liu (2011), these HL community-based programs often do not have enough funding to own an appropriate facility for their activities. The FVFP currently is found in three different counties in South Florida: Miami-Dade, Broward, and Palm Beach. In order to establish the space for their classes, the school has partnerships with companies and religious organizations to use their available rooms for no charge. The interviews for this study took place at the Miami-Dade unit.

\section{Description of the Participants}

I interviewed five adults, three coordinators and two teachers working at this HL community-based school. All the participants were adult women born and raised in Brazil, ages ranging between 30 and 45 years, and who had immigrated to the U.S. In order to preserve the participants' anonymity, I selected pseudonyms for them. From now 
on, the two teachers will be referred to as Ana, and Sandra, and the three coordinators as Linda, Carolina, and Barbara.

All participants reported that they were confronted with the same gender issue when they left Brazil: they were following their husbands. They all needed to reestablish their professional life in a different country, with no family helping to raise their children. Two of the subjects worked as teachers in Brazil, one as a Portuguese language teacher, and the other one as a Spanish teacher. After arriving in the U.S., the Portuguese teacher went through all the processes necessary to validate her teacher-license, and she now also works as a Portuguese teacher in Miami-Dade County. At the time of this research, the Spanish teacher had not yet initiated the licensure process because she felt insecure about her English proficiency. A third participant became a teacher after arriving in the U.S.; she works as a Math teacher for special needs students in Miami-Dade County.

\section{Data Collection}

A qualitative research design based in semi-structured interviews was selected in order to facilitate learning about complexities of a curriculum development process not yet formalized or written. Based on Seidman's (1998) proposal, this research used the "three-interview series" in order to understand how a school's personnel develops its experiences, context, and meaning. The "three-interview series" entailed meeting with the participants over a 2- to 3-week period, hopefully reducing the impact of the uneven disposition of the participants one might expect from a single interview. In addition, this method enabled me to create a positive relationship with the participants. 
The data collection took place during Saturday classes in a South Florida program unit. The primary source of data was the interview transcripts, as well as the notes that I took during the interviews. The school's website was also considered as a data resource.

The recruitment of participants took place at the school, and participants were selected based on time criteria, such as their having at least one year of involvement in the school's activities. The researcher visited the HL community-based school during three consecutive Saturdays in order to first explain the research and identify participants and then conduct interviews and collect documents related to the school's curriculum development process.

In order to guarantee the participants' anonymity in all interview-transcripts and documents, I did not collect personal information; thus I will not include participants' real names in order to give them confidentiality. Additionally, I promised to store all the research information in a password protected personal laptop, which was kept in a locked cabinet for 1 year.

\section{Interviews}

Interviews are defined as a purposeful conversation between two people directed by an individual who wants to get information from the other (Morgan, 1997). This study conducted all interviews face-to-face, and participants were cooperative and eager in to share their experiences. I reaffirmed the purpose of my research before starting each interview, and I remembered their right to discontinue participation at any time. They read the Adult Written Consent (Appendix, A) and signed it before start the interviews. All the interviews were audio digital recorded with the consent of the participants. 
Before starting, my intention was to interview two teachers and two directors of the program. However, on my first day at the program I met a unit coordinator, who, during a long and informal conversation, showed herself to be quite open, providing information about the school's structure and funding. I took this opportunity to collect even more data, and I invited her to participate in the research. When I first met the participants, I explained my purpose and shared with them my Research Informational Letter (Appendix, B). The director of the program directed me to three teachers, based on time criteria and commitment to the program.

My next step was to contact the participants personally and discuss the purpose of the research, their doubts, and scheduling the interviews. However, one of the teachers opted out of participating after I contacted her; as a result, I was left with the remaining two teachers. I visited the school over three Saturdays. During this period I interviewed two teachers, two coordinators who were also founders of the program, and the one unit coordinator, who also participates in the program as a member of the directory. I interviewed each of them two times and each interview lasted approximately 20 minutes.

We spoke in Portuguese, both my primary language and the primary language of the participants, in order to make them comfortable in expressing their thoughts, experiences, and impressions.

I recorded the interviews using a telephone recorder and transcribed the recordings in order to preserve the words of the participants during the data analysis process. The goal of this strategy was to give participants more confidence that their words will be treated responsibly. At the same time, this method yielded me more reliability within any subsequent data analysis because I could pay attention to participant 
expression "as fully and as accurately as possible" (Seidman, 1998, p. 117). Recording the interviews also permitted me to concentrate better on the flow of the conversation during the interviews, thus allowing me to take notes of the data several times.

\section{Questions}

The purpose of my study was to answer the research questions: What roles does this HL community-based school aim to play for its students? Which is related to the subsidiary question: How does this HL community-based school organize its curriculum development process? In order to understand the participants experience and thoughts about these two main issues, I elaborated the following guideline questions and their justifications:

- What is your educational background? Describe your professional experience before working in this organization. How did you become a teacher at this organization?

Asking these questions allowed me to verify what some researchers (e.g. Douglas, 2008) have observed as challenges of these programs. Usually, personnel do not have professional background in education, nor do they have experience in curriculum development. For them, I similarly elaborated upon my original research question in the following manner:

- What are the general curriculum aims that this HL community-based school stands for?

Historically, the community-schools have promised to maintain and develop minority language and culture. Fishman (2001) argues that these programs are vital to 
preserving the languages in U.S. Some researchers (including Wong \&Lopez, 2000) concluded the most important function of these centers is to create a sense of cultural and ethnic pride, while providing an environment for children and parents to socialize with peers in their HL. As a result, within the interviews, I was prepared to ask the following subquestions:

- Did the school introduce to you a formalized curriculum that guides you to prepare your instruction? How did you become aware of your curriculum goals as a teacher in this school? How often do the teachers and coordinators discuss the aims for the students?

The significance of this question relies on understanding how teachers and coordinators share and elaborate their aims and curriculum goals. As a result, I added the following subquestions into my preparation:

- Did the school select any curriculum pedagogical approach as a main educational philosophy in which you could incorporate into your practices? Do you feel personally engaged by any pedagogical approach?

The significance of this question relies on understanding the beliefs that act as teachers' and coordinators' driven forces when integrating with students and knowledge, resulting generated the following guide questions:

- How are the groups organized in your school? How do you deal with the different backgrounds of your students?

Carol Compton (2001) remarked that the HL community-school offers classes from preschoolers to seniors. Consequently, students vary in age, background, and interest. Such conditions leave teachers with difficulties accommodating a wide range of students 
in classes (Duff, 2008). My intent was to understand how these teachers and coordinators deal with these difficulties and what strategies they developed for these challenges. As a result, I prepared the following related subquestions:

- Describe the process of preparing your classes. Are there any instructions that the coordinators or other teachers discussed with you? What are your learning expectations for your students?

As Posner (2004) described, selecting curriculum goals specific for students is important in order to set the characteristics that are supposed to result from learning over the years and across the subject matter of schooling. I attended to such by developing the following guideline subquestions:

- Describe the process of selecting contents for your classes. Did the school discriminate main topics or contents that are important for your specific group?

Usually, the main purpose of a HL community-school is to develop language abilities and cultural knowledge. However, some schools may choose to develop academic content such as math, science, history, and geography as important aspects of their curriculum. It is important to understand what knowledge that each community values and expects to develop, because such can show us the role that they expect to play in their community. With this question, I also expected to understand how school officials understand the cultural aspects that are used to participate in their curriculum.

- Describe your usual method to select contents and activities for your classes. Please, list your reference sources such as books, textbooks, blogs, educational sites, guidelines, magazines, or if you create your own activities. 
The purpose of this question was to have participants describe the regular method and sources established for preparing classes activities as instructional strategies of the curriculum development process.

- What are the materials used during a class? Who provides them?

As some researchers observed, these programs have many challenges, and one of them is the shortage of textbooks dedicated to this field (Duff, 2008).

- How do you evaluate your students' progress in HL language skills? How do you evaluate your students' progress in the cultural knowledge and contents development? Describe the frequency and products that you account for your evaluations.

The linguistic characteristics of HLLs differ from foreign language students and native speakers, strategies and instruments to assess their skills are still in developmental stage (Compton, 2001).

\section{Ethical Considerations}

Participation in this research involved no more than minimal risks of harm such as spending time to answer the interview questions related to pedagogical practices shared with the researcher. Before starting, I distributed an information letter to the participants explaining the purpose of the research, the time expected to spend on it, and the required activities. I also obtained the subjects' written permission and made clear that engagement in the research was voluntary. As a commitment to participants' confidentiality, I did not included their real names to guarantee the participants' anonymity in all interview-transcripts and documents. 
It is fundamental that researchers obtain approval to work with human subjects prior to starting involving the project. This study was conducted in accordance with the Florida International University Institutional Review Board, and its approval can be found in the Appendix (C).

\section{Data Analysis}

The aim of this inquiry was to learn about complexities of a curriculum development process not formalized or written. It was expected that teachers and coordinators would describe how they select aims, methods, continents, and instructional strategies when planning their interventions. The main data consisted of the interviewtranscripts, which were analyzed and connected as categories and themes to further organization, notes that the researcher took during the interviews, as well as the school's website. My objective was to identify patterns in the data that could be arranged in a relationship, analyze it, and discuss it in order to contribute for further recommendations in curriculum design considering the HL teachers and students' specific needs.

The transcriptions, as were the interviews, were in Portuguese, to assert reliability for subjects' expressions. During the transcription process, I corrected simple grammar issues in Portuguese, such as implied verbal concordance in order to clarify the relation between subject and verb during the Portuguese-English translation process. When I finished the transcription process, I printed two copies of the interviews' transcripts.

After reading the transcripts three times, I started the classification process highlighting passages with brackets. I selected parts that emerged as important, interesting, and that showed a consistent repetition among the participants' statements. 
Seidman (1998) observed that the process of reducing interviews' material is the first step of the analysis and interpretation of it.

After highlighting excerpts, I read the unmarked transcripts and compared them with the highlighted ones to make sure that I was not leaving behind some parts that could be important. In order to reduce and shape the material into a form in which it can be shared, I chose to develop categories. As Seidman (1998) suggested, I started to organize the material in "threads and patterns among the excerpts" (p. 127). In order to shape them in categories, I started to name excerpts and compare them to understand how they could be related and what the main issues were. The process of creating categories was ongoing; I organized and reorganized some categories during the reading process. Finally, I created stable categories and separated them in themes such as: educational concepts, curriculum organization, issues related to the program structure, and social issues.

\section{Educational Concepts}

- Participants' understanding about what means a school and what means recreation.

- Concepts such as language, learning, teaching, bilingualism, and literacy.

Issues related to the program's structure

- History of the program

- Structure 
- How teachers and coordinators prepare classes, materials used by students, main resources to prepare class activities

- How units and groups are organized

- Teacher's profile

- Relationship between the school and the community

- Accumulated and modified pedagogical experiences

Curriculum development process

- The needs of students and the community

- Fundamental concepts for HL education

- Curriculum goals

- Specify subject matter

- Instructional strategies and evaluation methods selected

After organizing the categories and themes, I continued with the interpretation process. This process is described in Chapter IV, and it allowed me to rethink the categories and to question myself in order to confront researcher subjectivity and to avoid possible biases.

\section{Role of the Researcher}

This qualitative research method is related to the researcher's function as the primary instrument for gathering and analyzing data (Merriam, 2009). However, the researcher assumes this position in an interpretative instance because the interviews, 
documents, notes, and observations are related to participants' social meanings for their experiences.

\section{Delimitations of the Study and Validity}

This research focused on describing and discussing the curriculum development process of a Brazilian-Portuguese HL community-school in South Florida. Consequently, a delimitation of this research is related to the specific context of the Brazilian community in South Florida, which maybe cannot be generalized to other contexts or different language communities.

This research also has a delimitation of relying in the school's personnel perceptions about the school curriculum development process, and further research should involve parents' and students' perspective about this process. Other issues are related to participants' dispositions toward talking and sharing their experiences. In order to reduce the impact of any uneven disposition of the participants in one-time interview, the researcher selected the use of the semi-structured "three-interview series" (Seidman, 1998).

\section{Chapter Summary}

This chapter presented and discussed the methodology used to gather data from the HL community-based schools' stakeholders in order to answer the research questions. The process selected was a qualitative research approach based on a three-interview series of three coordinators and two teachers from the school. The chapter also discussed and justified the interview questions and the ethical considerations of this method. 


\section{CHAPTER IV \\ FINDINGS}

This chapter provides findings from the transcribed interviews with teachers and coordinators, my notes drawn up during the interview, and the analysis of the HL community-based school's website. Findings specific to the research questions will be presented and discussed.

\section{The HL Community-based School Researched}

\section{Teachers’ Profile}

At Foundation Vamos Falar Português (FVFP), all teachers need to show previous experience in the educational field, and they receive payment. These characteristics differentiate the FVFP from other HL community-based schools whereas that latter usually rely on parents as volunteer teachers (Compton, 2001; Liu, 2006). At FVFP, students' high motivation can be indirectly linked to these aspects of experienced and paid teaching staff, as well as the instructional strategies selected by the school. However, more research is needed to understand if the aspects of inexperienced and volunteer staff actually influence in this Brazilian HL community-based school's effectiveness. In order to preserve the participants' anonymity, I selected pseudonyms for the two teachers: Ana and Sandra.

Although the FVFP teachers indicated experience in education, this previous experience was seldom related to teaching Portuguese in particular. Indeed, none of the 
participants in this study showed experience as literacy teachers. As observed by Ana: "I never studied Portuguese formally, or Education. Once I had a class on teaching methodology in Brazil, but it has been 10 years. I follow what works at the time" (interview with Ana).

In addition, the teachers said they chose to become teachers at FVFP in response to a personal calling or a sense of mission to maintain the HL. Seemingly, these teachers are engaged from their heart into helping families maintain and develop the children's language abilities for personal reasons, as Ana stated: "I work with bilingualism in children to know how a bilingual child functions. What is the difference between this and the learning of children who only speak one language... because I have two children and this is personal" (interview with Ana).

\section{Coordinators' Profile}

The three coordinators participating in this study were also members of the program board of directors. Excluding teachers, all other people involved at FVFP work voluntarily. In order to preserve the coordinators' anonymity, I selected pseudonyms for the three coordinators: Linda, Carolina, and Barbara. Barbara used to work as a Portuguese language teacher in Brazil. After arriving in the U.S., Barbara went through all the necessary processes to validate her teacher license, and she now also works as a Portuguese teacher in Miami-Dade County. Linda became a teacher after arriving in the U.S., and she works as a Math teacher for special needs students in Miami-Dade County. Carolina is the unit's coordinator, who has information about the school's structure and 
funding. However, she does not have experience in the educational field; in Brazil she worked as an executive secretary.

\section{Description of the Documents Examined}

The documents used to examine the HL community-based school curriculum were composed principally of the transcriptions of the semi-structured interviews with the teachers and coordinators. However, I also used notes related to the school's aims, methods, contents, and instructional strategies that I took during the interview process. In addition, the school's website was also considered as a data resource.

\section{Findings Based on Research Questions}

This investigation mainly relied on the school workers' perspectives to understand the following research questions: (a) What roles does this HL community-based school aim to play for its students? And subsidiary question: (b) How does this HL communitybased school organize its curriculum development process? During the study, I searched the program's website and observed that only one aspect of the curriculum is actually written: the general program's aims that are equivalent to the roles that the FVFP aims to play for its students and around community. 


\section{What Roles does this HL Community-based School Aim to Play for its Students?}

On the school's website, there is a description of the program's mission that I considered very consistent with what I heard in the participants' interviews. However, on the website the FVFP also enumerates complementary goals dedicated to the general Brazilian community in South Florida that were absent in the school workers' discourse:

1. To create opportunities and raise children's interest in speaking Portuguese during program's cultural activities;

2. To stimulate daily oral expression and fluency in Portuguese, diminishing a possible language loss;

3. To awaken Brazilian citizenship, promoting respect for the heritage identity in order to participate in the Brazilian community;

4. To increase the value of the Portuguese language fluency in the Brazilian community as a means of increasing career opportunities for HLLs;

5. To act as a community outreach program that unifies and discusses community necessities;

6. To value the cultural reality of children and young adults, offering new cultural ways to belong in the society;

7. To boost plural identities that characterize the Brazilian culture, the Brazilian community in the U.S., and the regional community;

8. To promote understanding of the relationship among concepts such as culture, cultural diversity and citizenship; 
9. To contribute to Brazilian community economic strength, attracting Brazilian investors to South Florida;

10. To promote cooperation among institutions, companies, and communities;

11. To stimulate value for Brazilian culture within the community;

12. To create storytelling groups;

13. To induce children and young adults to HL literacy (Fundação Vamos Falar Português, 2012)

These general aims stated on the school's website will be compared with participants' discourse of the roles of the school.

\section{Coordinators' and Teachers’ Discourse of the School Roles.}

In order to observe to what degree teachers and coordinators mirror the aims expressed on the program's website in their practice, I asked teachers and coordinators about the social needs and situations that they are trying to address. Further, I compared their answers with the program's general aims presented at the FVFP's website.

From the participants' perspectives, this HL community-based school expects to accomplish four goals:

1. To develop linguistic and cultural belonging in an HL

2. To maintain students' oral HL abilities

3. To enhance children's pride in speaking a language other than English at home

4. To make parents aware of the family's crucial role in raising a bilingual child. 


\section{To develop linguistic and cultural belonging in an $H L$.}

This first goal is related to the social need to develop a strong connection between any student and that student's parents' language and culture. As the pedagogical coordinator, Barbara, explained when I asked about the main goal of the school:

The intention is to make students feel comfortable when they go to Brazil. That is

it. But it is not just a matter of comfort, but also a matter of identity, the feeling of being Brazilian a little bit as well. Not like a tourist, Brazil is very beautiful and I want to get to know Brazil... the way to view of this little Brazilian has to be different from the tourist; it is not just about going on vacation and coming back. It is about identifying himself and feeling proud of the Brazilian culture, even if living his whole life over here, even if he never goes back there. He will feel comfortable, and he won't feel ashamed of saying that he speaks Portuguese. (interview with Barbara)

This first goal attempts to address some situations occurring when a child visits their extended family abroad, or when the extended family comes to the U.S. It is common in this situation the child feels puzzled by the cultural differences. This situation usually occurs because the child does not have cultural knowledge or understanding of the cultural dispositions - a situation aggravated if the child has difficulties expressing in the family language.

The goal of developing linguistic and cultural belonging in a HL can be linked to the first aim stated on the program's website such as: to create opportunities and raise 
children's interest in speaking Portuguese during program's cultural activities; to stimulate daily oral expression and fluency in Portuguese, diminishing a possible language loss; to awaken a Brazilian citizenship, promoting respect for the heritage identity in order to participate in the Brazilian community (Fundação Vamos Falar Português, 2012).

\section{To maintain students' oral language abilities.}

In order to keep family attachment, teachers and coordinators think that it is important to maintain students' oral language abilities. This aim is designed to address some situations observed by parents, as stated by Carolina:

When it is vacation in the U.S., [the children often] go to Brazil, and the children tell the parents that [they] did not like their trip. [The children report that] Brazilian friends and family usually make fun of them because [they] do not speak Portuguese, so they feel embarrassed. So, when I heard the parents talking about these experiences, I invited them to bring their children to the program. (interview with Carolina)

This second goal of the program is linked to the first one. The idea is the child creates knowledge and connections with the HL and culture in order to prevent feeling as a foreigner in their parents' country. This goal aims to help students improve their interaction and integration with their extended family. As it was affirmed by the pedagogical coordinator, Barbara: 
The expectation that we have for the student is not to be embarrassed of speaking in Portuguese, that he is able to communicate with his parents or family in Brazil, that he does not feel alienated and that other people are in the same situation as he is. (interview with Barbara)

Coordinators also considered the goal of enhancing children's HL linguistic abilities in favor of a globalized context in South Florida, where Brazilian-Portuguese has become important and distinctive to the regional workforce. This can be observed in Carolina's statement:

In this country, when these children grow up to speak three languages will it not be something! I alert the parents that children will charge them in the future for their not speaking Portuguese. The Brazilian community has been growing a lot here in South Florida, [and] in New York too. (interview with Carolina)

As Jouët-Pastré (2011) observed with university students of Portuguese as a HL, this more instrumental motivation linked to future job opportunities has been more commonly used by students since the Brazilian economy has been occupying a prominent position in the press. However, Jouët-Pastré's research showed that the integrative motivations based on family attachment and identity issues continue to be stronger than the practical motivations. At FVFP, teachers and coordinators convince parents to bring their children to the Saturday classes based on both arguments. As Linda, the coordinator 
observed: "we are also thinking about the children's future jobs opportunities" (interview with Linda).

\section{To enhance children's pride of speaking a language other than English at home.}

The program's third goal is the creation of opportunities for children to meet and interact with peers who speak the HL. Participating in the community-based school helps students to soften the idea of being different. Moreover, the teachers observe that doing so also enhances children's pride of speaking a language other than English at home. As Linda states: "Generally, the children are ashamed to speak Portuguese around other children, so here they see many children speaking Portuguese. So they think: it is all right to speak Portuguese" (interview with Linda).

\section{To make parents aware of the family's crucial role in raising a bilingual child.}

The school understands that the family is the one responsible for keeping and developing the children's bilingualism; thus the school gives parents an important support on that, as observed by Linda, the coordinator: "I think the program is a drop of stimulus to the family" (interview with Linda), and Carolina, the unit coordinator: "Parents need to teach, show the meaning of learning Portuguese and to keep the language in use. For me, what parents do at home is part of the program" (interview with Carolina).

At FVFP, the coordinators understand that educating parents is the key to improving children's languages abilities. As the coordinator, Linda, observed: 
it is more a stimulus, a parent education, because you see both parents are Brazilian and they speak English with their children! So we work hard to educate parents about why it is important to speak Portuguese with their children. (interview with Linda)

The FVFP assumed the role of educating parents about how to maintain and develop a HL at home. The most difficult task seems to be convincing parents to speak and to make their sons and daughters answer in the HL at home. The coordinators assumed the function of talking with parents, asking about their language use at home, discussing methods, and convincing them of the children's future gains in preserving an HL.

As observed before, one coordinator stated that parents feel that, after participating in the program, they change their own relationship with their primary language, and this leads to great consequences in order to enhance their children's bilingualism. As Linda stated: "During these eight years of the program, parents keep telling me that after participating in the program they started to speak Portuguese at home, they started to watch the Brazilian TV channel. They came to me to say thank you" (interview with Linda).

As part of its educational purposes, the program usually promotes Saturday educational meetings between donors and parents. As an example, a Brazilian dentist, who supports the school, spent 1 hour talking with parents about dental hygiene. Other examples occurred during the Mother's Day celebration, when Brazilian beauty salons 
offered services to the mothers. These initiatives also have the function of promoting parents' socialization while students are in classes.

\section{Comparison between the program's written general aims and participants'}

\section{discourse.}

On the school's website, the first description of the program's missions can be mirrored by the coordinators' and teachers' discourse including notions such as developing linguistic and cultural belonging in an HL; maintaining students' oral HL abilities; enhancing children's pride of speaking a language other than English at home; and making parents aware of the family's crucial role raising a bilingual child. We can affirm that the main aims of the HL community-based school are to accomplish these four goals as confirmed by the interviewees' responses. However the goals addressing the contributions to the general Brazilian community, which were listed in the website, were not mentioned by teacher and coordinators during the interviews.

\section{How does this HL Community-based School Organize its Curriculum Development Process?}

After understanding the roles that the HL community-based school studied aimed to play for its students, this investigation looked to answer a second research question: How does this HL community-based school organize its curriculum development process? During the study, I examined the program's website and observed that only one 
aspect of the curriculum was written: the general program's aims. The other curricular aspects not written were, however, evident in the coordinator and teacher discourses, and I have organized such corresponding comments into the following categories:

- The school philosophy of education and some fundamental concepts;

- The school curriculum goals;

- The subject matter selection; and

- The instructional strategies valued.

Consequently, based on participants' understanding, I organized a basic structure that can describe the school's operational curriculum. I also analyzed this intuitive curriculum and discussed its aspects.

\section{Fundamental concepts for heritage language education.}

Coordinators and teachers seemingly hold some fundamental ideas about education and important concepts related to this type of program. These valued ideas act as driving forces that shape FVFP teacher-student interactions, class preparations, and evaluation. They express the program's understanding about what school is, their perspective about the teacher-student relationship, and fundamental concepts such as literacy, bilingualism, and language learning.

\section{Participants' understanding of what a school is.}

From the first interview, teachers and coordinators refused to use the term school to classify their activities. In order to create a possible explanation for this, I selected and analyzed all the excerpts in which the participants reflected about the term school. It 
seems that participants understand school based on their experiences as students in Brazil, as Sandra stated:

At least what I remember from school is that you have to sit down at a desk and copy what the teacher writes on the board and that thing about theory, theory, theory... and I think this is boring for most kids. I remember that I used to be bored. I stayed there, copied everything, knew everything, but there was nothing practical. And when there was a practical class it was like heaven. (interview with Sandra)

I assumed that the participants recalled these experiences in order to oppose the program's activities as a school, as Barbara observed:

This is a classroom that doesn't try to be strict, not full of rules like the school has. Well we have rules, but we don't have grades. The student does not need to pass the class... The student does not need to complete, achieve a grade to pass the class... (interview with Barbara)

As I consistently questioned why participants did not see their activities as a school, they justified the conclusion with the following aspects: low frequency of the classes, the non-use of tests in evaluating their students, the focus on hands-on activities in order to motivate students' participation, and the idea that the goal of the classes is to provide interaction between Portuguese speakers through recreational activities. As 
examples, I selected statements by Linda - "The teachers ask me how to do, [discipline students], because we are not a school we cannot give zeroes to a student to make him/her to stay quiet" (interview with Linda) - and by Ana - "The idea is not to oppose the method that is used in schools, it is because we only have 1-hour per week, we have to do something to get their attention, something they like" (interview with Ana). In light of these issues and comments, I questioned Barbara, the program's pedagogical coordinator, who offered these statements:

If we use the term school in the greater meaning of a place of knowledge, [it is] like a place where you get together with other people and that there will be a person to guide you so you may find out new things that you don't know and discover things that, alone, you would not discover. This way, yes, a place where knowledge is being passed around and produced! Then yes, the FVFP is a school. But if we use the term school with a narrower meaning - a place where I go and there is a teacher that stays up front and asks me to open a notebook and write, and at the end of the week I will have an exam, and I have a break for recess, [and] afterwards I go back and remain seated and I keep learning - then the FVFP is not a school. (interview with Barbara)

\section{Participants' perspectives about their teacher-student relationship.}

In the participants' view, the teacher-student relationship is hierarchical, as Barbara declared: "The teacher has something to give, and students have something to receive" (interview with Barbara). In their perception, teachers have the knowledge and 
need to be respected and listened to. The teacher leads the activities during the class. However, the participants also showed that this hierarchized relationship is flexible and students' expressions are appreciated and incentivized, since the students do not break class flow. As the teacher, Ana, illustrates:

I try not to be that authoritarian figure in the classroom. I talk, ask them how their week went, what they did. I try to make them feel important. I have to make them talk, and not have them think that they will be judged by an authority figure, like that. (interview with Ana)

\section{Participants' understanding of what bilingualism is.}

It seems that coordinators and teachers understand bilingualism in a narrow perspective. They related a bilingual person as one who shows proficiency in standardized grammar, and possesses a native language accent. The restricted understanding of bilingualism is linked to teachers' affirmation that is prejudice for the students not possessing a native-like accent, as Sandra observed: "They will have an accent, they will speak like an American speaking Portuguese, without verbal agreement, I see this" (interview with Sandra). When speaking an HL and visiting Brazil, the students will face the extended family expectations that these children speak fluently and with native-like accent, differing from a foreign language learner.

One interesting and important view about bilingualism is related to the local community. The perception of a multilingual South Florida social context became a justification that supports the program to show the importance of bilingualism to the 
parents, as Carolina's previously statement observed: "In this country, when these children grow up to speak three languages will not be something!" (interview with Carolina).

Relating bilingualism and identity, a valuable idea is that teachers think that is important to respect the fact that these children are Americans at same time that their families want to nurture a Brazilian identity. Teachers see it as important to value these bilingual children's multiple identities, as well as to help parents embrace this concept.

\section{Participants' understanding of what literacy is.}

All the teachers and coordinators stated that their program is not designed to develop literacy skills in their students. As an example, Ana stated: "Formal instruction in reading and writing was never the Foundation's goal. It was always to maintain Portuguese in some way" (interview with Ana).

However, participants' statements contradict their practices when they describe promoting activities that aim to teach children to read in Portuguese. As an example, I selected Sandra words: "I use the syllabic method, but I don't label anything. I talk about the families of $l a, l e, l i, l o, l u$, like this" (interview with Sandra), and

Sometimes we do dictations, and we have them repeat the words. The group of 5to-6-years-old: they are mature enough for that. They already know how to write 
frog, horse, pig, and they are mature enough to see the syllables, but I don't call it syllables, I call it piece. (interview with Sandra)

Although teachers stated that literacy is not a goal, coordinators hold literacy expectations, aiming learners towards developing reading and writing skills, as Linda, one coordinator, observed:

We are also thinking about the children's future job opportunities. These children will learn one more language, and to enter the workforce, it is not enough to speak. They also ask you to write and read in other language. You need to write correctly, a great vocabulary. So since these children are little, we think about that. (interview with Linda)

and Barbara, the pedagogical coordinator, stated:

The goal is to allow the child to have contact with the Brazilian culture, language, and literature. We don't formally teach how to read and write. Our goal is not to teach formally how to read and write in Portuguese, but to have the child be able to read, write, and talk...to communicate in Portuguese... Writing includes from words - the use of a dictionary, recognizing meaning, putting words in short sentences - to text production. So, on top [is the] trio: reading, writing, and oral communication. The classes are prepared with these goals. All the classes have to work with reading, writing, and oral communication. (interview with Barbara) 
The idea that literacy is not a goal also contradicts the general program's aims stated on the FVFP website: "To induce children and young adults to HL literacy" (Fundação Vamos Falar Português, 2012).

\section{Participants' understanding of what a language is and how languages are acquired.}

Most of the participants, in different contexts and repeatedly, linked language with grammar proficiency. It seems that participants understand that language is learned through repetitive grammatical exercises, which, in their view is an activity that contradicts the program's curriculum instructional goal in offering recreational activities to their students. As Sandra, a teacher, observed:

They have the English grammar in their heads (...) In their little heads it is simple, because they already have the influence from English, and [here] they don't have grammar classes. And we don't even want them to...Over at their school, they already have grammar and go on internalizing the grammar from the English language, the same way I had when I learned Spanish; I kept doing grammar exercises. (interview with Sandra)

Sandra statement indicates that some teacher thinks that language acquisition is related to grammar exercises. Other teacher also observed that older children show more resistance to speak the HL during the classes. They think that this occurs because older 
children are repeatedly practicing grammar exercises in the dominant language at the regular school. Related to the idea that Ana observed that what she sees "is that the resistance of the older children is greater than that of the younger ones", (interview with Ana), and "They will speak in English. My fight is lot stronger against them, because they will speak more English in class than the younger ones," (interview with Ana).

\section{Curriculum Goals.}

The idea of establishing curriculum goals is important in elucidating the expectations that a school holds for its students. These goals usually represent values, knowledge, and attitudes that a school respects and expects that students will learn and develop during the time. The interviewees did not clarify what expectations the program holds for its students, specifically those goals related to developing students' language abilities. As Ana, a teacher, declared: "In reality, now that you mention it, the foundation has a goal for sure. For me, my goal is to talk in Portuguese in some form, that [students] leave that classroom, and they keep talking in Portuguese" (interview with Ana).

Regarding FVFP's curriculum goals, participants reported them as too general and with continued need to be deeply discussed, as Barbara, the coordinator observed:

The expectation that we have for the student is not to be embarrassed about speaking in Portuguese, that he is able to communicate with his parents or family in Brazil, that he does not feel alienated and that other people are in the same situation as he is. (...) We have these expectations, but we know that 15 classes are not enough. The children that are with us for several semesters, we see that 
they are improving. We see that they are speaking better, that they [have] started to write and read in Portuguese, that they understand more when others are talking to them. Our expectation is the child is able to communicate. (interview with Barbara)

Teachers particularly were confused if the curriculum goal of the school was to maintain students' oral abilities or to develop cultural knowledge. As Ana stated: "So if I had to talk about the Foundation's goal, it is always maintaining Portuguese as part of these children's lives (interview with Ana), and Sandra: "In reality, we teach culture classes" (interview with Sandra). However, for the coordinators it was clear that they aim to maintain children's language abilities as well as to develop linguistic cultural knowledge in order to create a bond with the HL. As Linda observed: "They grow up and they learn about the Brazilian culture and keep speaking Portuguese when they become adults. The intention is to show a little bit of Brazil to them" (interview with).

\section{To maintain HLLs' oral language abilities.}

It was clear for the coordinators, however not for teachers, the school's aim was expanding student's oral abilities to different domains and registers. When I approached the issue of working with different language oral registers in different social contexts, Ana stated: 
[The focus of language work] is more informal. Sometimes I show that one does not write pra mim, but para mim... but we are not worried if the Portuguese is formal and correct. Like I said, it is only one hour of class, and we don't have time for this. The main goal here is to maintain the language. What is the way to maintain the language? It is by talking, so the base of our work is oral communication. (interview with Ana)

\section{Cultural knowledge.}

It is a common goal of HL community-based schools to offer classes based on cultural knowledge. At the FVFP, the participants perceived the importance of teaching culture in order to make the child feel comfortable when the child meets the extended family here in the U.S. or abroad. As Sandra observed:

They interact with the family over there and they are better prepared for the interaction once they go there. If not, everything would be very new, like a shock; I am speaking English, and suddenly then I have to speak Portuguese in a country where I don't understand anything. (interview with Sandra)

This goal shows that teachers and coordinators view cultural knowledge as creating a disposition of belonging to an HL. As Sandra believes: "Our focus is the cultural ties, to create a bond with Brazil, that they feel that Brazil is their country as well" (interview with Sandra). However, this idea does not recognize the internal aspects 
of humans, such as motivation, and also how the family values and acts to embrace their multiple identities (Posner, 2004).

\section{Subject Matter.}

As observed by Kelleher (2010), HL community-based schools usually organize their classes based on culture, traditions, and contents, such as holiday celebrations, rather than focusing strictly on language as the object of instruction. At the researched school, the pedagogical coordinator defines the subject matter before each semester begins. The teacher, Ana, declared:

There are 15 Saturdays a semester. So [the coordinator] sends the topics that we will work with on Saturdays. This day we will work with Christmas. There is a guide, but the classes are not ready. We will work with that on that Saturday, and start researching about it beforehand. (interview with Ana)

FVFP is aligned with Almeida Filho's (2008) observations that the majority of Brazilian-Portuguese HL community-based schools organize their curricula based on themes related to the HL culture. Barbara, the coordinator, who defines the themes, stated:

this is more important for those who live abroad and do not live the Brazil of every day. It is important to know how the people live over there, knowing a little bit about Brazil (...) knowing the folklore, the traditions, the superstitions, the 
food, the music, the dance, the flag, and why Brazil's flag is the way it is... In the end, all these representations are part of a country and its people. Even if you live far [away], it is important to know this because when it is time to visit, you know why they kiss three times, when people greet each other, even when not knowing the person, why we hug and kiss: the intimacy level even without having seen the person before - things that you learn only by living in that country, things that we try to show them a little bit. (interview with Barbara, 230-242)

At FVFP, the coordinator selects themes involving the HL folklore, the families, and specifically related to Brazilian culture, the indigenous populations, the geographical and cultural regional differences, the typical foods, and the popular Brazilians holidays and festivals, such as Carnaval, Festa Junina, and the Independence Day.

\section{Curriculum Planning.}

Participants stated that at FVFP, during the semester, teachers and the pedagogical coordinator exchange emails to discuss class activities. The teacher, Ana, shared during the interview: "What we do in the beginning of every semester is to have all the teachers meet and each one has an idea. Then the best ideas are chosen and each one plans their own class" (interview with Ana).

Usually, at the beginning of the week, the coordinator sends an email to the teachers with suggestions about the themes for the class activities. They start to discuss possible activities, and the coordinator guides them in order to verify the adequacy of those activities. 
Although the teachers and the coordinators have consistently communicated during the semester, one participant could not detail what the program roles were. Another interesting aspect was that Linda, one coordinator, understands that because everyone is a teacher: "they speak the same language" so "the discussions are very fast" (interview with Linda). It seems that they have been discussing practical issues efficiently; however, consequently, less attention is dedicated to discussing main educational concepts.

The participants usually divide the 1-hour activity in 30 minutes presenting the theme and introducing new vocabulary, and 30 minutes of hands-on activities for vocabulary reinforcement. Teachers have considered the first part more "traditional oriented" because they usually read a text and ask learners to fill out worksheets. In the second part of the class, teachers use hands-on activities utilizing arts and crafts, videos, and music. Participants also aim to keep the conversation going, requiring HLLs to speak Portuguese in order to create opportunities for teachers to correct grammar issues, such as irregular verbs. As Sandra observed: "This is the goal, that they start to talk. Eu fazo não, eu fiz...eu pozo não, eu posso. Then there are the silly mistakes that we go on correcting" (Interview with Sandra).

The teachers participating in this research tend to consult mainly Internet resources in order to collect ideas and activities to prepare their lessons, as Ana observed:

We use a lot the website SmartKids.com.br because they have many activities. It is good for small children, and they have almost everything. But their Portuguese is not very good, so I don't use their text directly in class. But they have many 
activities, many ideas of activities, pastime. They have many things for coloring. I also use the site sóportugues.com.br for grammar itself and whatever else they provide (interview with Ana).

The resources vary from Brazilian programs dedicated to children on YouTube, Brazilian literacy teacher's blogs, and Brazilian websites dedicated to literacy and recreational activities. They usually do not use textbooks as reference because they do not have access to them. Furthermore, they do not see that Brazilian textbooks dedicated to native speakers are adequate to HLLs specific needs. As Barbara observed:

Following Brazil's curriculum is not going to work. We already tried using teaching materials from Brazil...the parents already wanted us to use a primer to teach reading and writing... in the beginning we used to teach cursive writing, using the primer, but it does not work because the students do not have enough vocabulary, and previous cultural knowledge presented in the books. After I started to work with themed units, everything worked out. (interview with Barbara)

After detaching from the Brazilian school system mainstream curriculum, the program still had maintained, for a period, the language approach based on repetitious exercises about grammar nomenclature and classification. This method is constantly used in Brazil in order to account for school tests. However, this metalinguistic focus appeared inappropriate to an HLL because grammar nomenclature seems to be meaningless and 
useless for HL children needing to improve their oral language abilities and develop cultural knowledge.

As observed before, despite the participants' non-goal of developing student's literacy skills, all the teachers and coordinators described using literacy activities for fiveyear-old students and older. They reported working with new vocabulary related to the themes, as well as engaging in reading and writing activities. When I asked Ana if all activities were designed to be oral, she described: "Orally and written. They had to draw and write the characteristics [of a character]. Like we did in class" (interview with Ana).

\section{Instructional Strategies.}

At FVFP, the semester lasts 15 classes, and the curriculum's program is thematic: the coordinator selects themes that teachers will follow to prepare the classes. The teachers usually explore each theme for a two-three weeks period. There is a general articulation-related concern that all the units offer the same theme and activities each class, as Linda observed: "We have curriculum organized by semester and all the units need to follow it." (interview with Linda). The general coordinator observes teachers during the class to help them to conduct activities as well as to verify if teachers are following the established and discussed subject matter and instructional strategies.

The program does not evaluate the students' outcomes in order to understand how the classes influence their language development. Students are mainly grouped by age, however, when the setting and funding structure permit, teachers and coordinators also 
try to group the children by age and level. In any event, a student's evaluation is always based on teachers' perceptions, as Ana observed:

There is no formal evaluation. (...) The coordinators and I sit down and talk, 'look this student cannot pass to the next group, according to my evaluation.' This is not in written form, but in oral form: how the kid is opening up, developing in class, if he is talking more, less; if he is using agreement, plural. I evaluate orally how the child is speaking. I do not evaluate the writing, because we don't write a lot. (interview with Ana)

As observed before, at the time of this study, the students were mainly grouped by age because of practical issues such as limitations on setting and funding. Barbara, the coordinator, shared that they needed to abandon grouping students by proficiency:

It was not even possible to pay a teacher teaching a class of two or three students. We had a waitlist for the beginners and an advanced class with three students... we decided to open one more beginner group. (interview with Barbara)

\section{Task-based instruction.}

As an instructional strategy, the FVFP uses a task-based approach in order to motivate students in their learning experiences during the classes. In this strategy, the teachers create an environment that targets learning the language itself, but the style of 
the instruction places emphasis on interactions using conversation and tasks requiring language use.

Some researchers, such as $\mathrm{Wu}(2008)$ and Douglas (2008), have indicated that content-based curriculum approaches, such as task-based, are more effective to HLLs, because such practices foster respect for the students' previous language skills. Such attitude was highlighted at the community-based school studied when Sandra stated: "we want [students] to learn by playing [with] activity more directed towards the language but without labels" (interview with Sandra). Barbara also observed: "The child needs to have contact with the language through reading, writing, and talking" (interview with Barbara).

However, teachers and coordinators showed some contradictions and misconceptions about what a task-based lesson is, as Linda described: "Well, because we only work 1-hour per week, we cannot say that the students will leave the program speaking and writing, because we focus on teaching the culture" (interview with Linda).

\section{Lúdico.}

All coordinators and teachers stated that recreation was the aim of their instructional strategies. The participants used the Portuguese word lúdico in order to classify their instructional strategies' aim. Lúdico can be translated as playful and recreational, where the goal is to bring pleasure. Linda, the coordinator observed:

It is like the child does not see [lúdico] as learning; however, at the end, they learn a lot, much more than if the teacher was just saying words that the children need 
to writing down in the paper, or if they need to memorize a list. (interview with Linda)

This idea is one of the aspects that can explain the positive experience that the FVFP's students have, as Ana, one teacher, observed: "When we are doing activities with our hands, they get involved and don't want to leave the classroom" (interview with Ana), and "because we only have one hour per week, we have to do something to get their attention, something they like" (interview with AP).

However, it seems there is some contradiction and some conceptual misunderstanding about what learning is when the discourse of the participants separate learning experiences from the playful activities. They separate the learning and comprehension part from the hands-on activities part of the class: 30 minutes of "content", or "traditional teaching", and 30 minutes of "recreational activities", as we can observe in Linda's statement:

Let's say that we have a theme. We have one-hour class. A half hour is about comprehension, discussion, writing. The last half hour, the students will work with their hands. It will be a game based on the theme. (interview with Linda)

\section{Chapter Summary}

This chapter presented results and findings from the analysis of the HL community-based school roles and curriculum development process. The analysis was based on teachers' and coordinators' perspectives, and utilized mainly the transcriptions 
of semi-structured interviews, as well as my notes taken during the interview process. The school's website was also considered as a data resource. The curricular aspects presented in the participants' discourse were also organized and analyzed and will be discussed in Chapter V. 


\section{CHAPTER V}

\section{CONCLUSION}

This chapter discusses the findings from the interviews with teachers and coordinators from a Brazilian-Portuguese HL community-based school in South Florida. First, the researcher will discuss the roles of the HL school and make a comparison with other programs from different ethnic groups. Next, the curriculum of the HL program studied will be discussed, as well as further recommendations to improve the program effectiveness will be made. The chapter ends with a conclusion and recommendations for teacher training courses considering the school necessities.

\section{Roles of the HL Community-based School}

The HL community-based schools have been recognized as an important support for language maintenance for young HLLs. You and Liu's (2011) research of Chinese and Korean HL schools in the U.S. concluded that in the stakeholders' perspectives, these schools act as major agents to prevent "language shift" and promote language maintenance, as well as to help students form a sense of cultural ethnic identity.

As Lico (2011) observed, since the 2000s, there is a more consistent effort from the Brazilian immigrant community in the U.S. in order to preserve its language and culture for the next generations. As this study indicated, The Foundation Vamos Falar Português (FVFP) is an HL community-based school that, according to the participants, assumed four main roles: developing linguistic and cultural belonging in an HL, 
maintaining students' oral HL abilities, enhancing children's pride of speaking a language other than English at home, and making parents aware of the family's crucial role of raising a bilingual child. These roles were organized in response to general societal needs observed in the local Brazilian community.

However, at the FVFP's website, there were goals addressing the program's contributions to the local Brazilian community such as to contribute to Brazilian community economic strength, and to promote cooperation among institutions, companies, and communities. These goals were not mirrored by the coordinators' and teachers' discourse. I understand that the lack of attention to these ideas means that these roles are less prominent functions of the program.

Two of FVFP's main roles are similar to Lico's (2011) conclusions about a Brazilian HL community-based school in Washington DC area. There, Lico observed two principal roles aimed by the program: supporting and educating parents to maintain and develop their children's language abilities, and enhancing children's pride of speaking other language than English at home.

The goals addressed by these Brazilian HL schools are also similar to Lu's (2010) ethnographic study of HL Chinese schools in the Chicago area. The study verified that many parents believe that through the language, their children can learn their history, culture, and values; the children will be able to communicate with grandparents and relatives; and they will find a place to meet and socialize with other kids in the HL. Almeida Filho (2008) considered that the main challenge of these programs has been to create a linguistic and cultural belonging for the second generation of immigrants, and according to the participants, FVFP seems to be accomplishing this function for its 
community.

\section{Parental Engagement and Education}

This study observed a difference in parental engagement between the Brazilian programs and the Chinese HL community-based schools previously studied. As FVFP teachers and coordinators described in South Florida, and Lico (2011) concluded in the DC area, the two Brazilian HL schools intend to educate parents. However, at Chinese schools parents have been playing different and crucial roles such as school administrators, project coordinators, fundraising coordinators, material and curricula developers, and teachers. Consequently, at Chinese ethnic group, parents are responsible for keeping the schools running successfully, and the schools have depended largely on parents in terms of financial support, and human resources, as Li (2005) concluded.

At Brazilian schools parents apparently have a less active participation and need permanent incentive and support from the school in order to continue speaking the HL at home. Further research is needed to understand why educating parents is a concern for Brazilian HL schools, and if other ethnic groups did not observe this issue as a necessity. At FVFP, the coordinators assumed the function of talking with parents about their language use at home, discussing language use methods, as well as convincing parents of the children's future gains in preserving a HL. The most difficult task seems to be convincing parents to speak in the HL themselves and make their children answer in the HL at home.

A similar aspect between the Brazilian school in this study and the one observed by Lico (2011) in the D.C. area is the teachers' perception that participation in the 
program change parents' own relationship with their primary language. Participants reported that bringing children to the HL classes has some effects on family attitudes, such as making parents recover their own ethnic cultural identity. Such effort is usually appreciated and valued by the extended family, and the children become more confident about the bilingual family choice. All these aspects lead to great consequences in order to enhance children bilingualism. Lico (2011) reached the conclusion that when the family decides to make efforts to keep the HL and culture in a natural flow at home, the HL community-based school serves as a great support.

Parents from the Chinese HL schools (Lu, 2001) described their positive perception about changes in their children since they started the weekend HL school. The Chinese parents noticed that their children have become proud of being Chinese, which has built their self-esteem and confidence. Lu (2001) also concluded that Chinese parents hoped that going to the HL school would help their children overcome identity crisis and become comfortable with their Chinese heritage in the future. Further research should account for parents' perceptions of how attendance affects Brazilian children related to identity issues.

Some interesting questions emerged from the discussion and comparison of these studies: How does parental engagement at the HL schools influence students' outcomes? How does a parental identification with its own ethnic identity influence children's bilingualism at home? Further research is needed to understand the differences between parents' engagement and their roles in Brazilian and other HL community-based schools in order to draw conclusions. 


\section{What does Maintaining Students' Language Abilities Mean?}

The common role of the HL schools from teachers' and coordinators' discourse in this and previous studies (Lico, 2011; You \& Liu, 2011; Liu, 2010; Li, 2005) was: HL community-based schools aim to maintain students' language abilities. The justification for this goal is keeping family attached, improving interactions and integration with the extended family. However, I detected a possible confusion between language maintenance and language development as a role of these programs in parents' and teachers' discourse.

As observed before, usually HL competence refers to the casual and conversational speech register used with familiar interlocutors and restricted to a set of topics focused on everyday life (Valdés, 1995). If these schools aim only to maintain students' language abilities, that means that the HLLs will likely not expand their usual oral familiar vocabulary and limited grammar. However, if parents, teachers, and directors perceive that participating at the HL classes the children expand their vocabulary and improve their grammar organization, these schools also have been serving as language development institutions.

Further research can indicate what is understood as language maintenance at these schools. In order for students to share their daily experiences with their family and keep sharing them in the HL while growing up, they need to expand their vocabulary in different domains from their immediate family life. Research can indicate if HL schools are being responsible for this expansion.

There is also need to investigate if parents, teachers, and directors of the HL community-based schools sustain an idealized language development expectation that 
could not be real from young HLLs. In my understanding, these schools need to approach language abilities and literacy development as a life-long learning journey, especially for early bilinguals.

Researchers are aware that these schools are a valuable resource for HL maintenance. However, some discussion of what is understood as language maintenance is necessary. I suggest that these schools can act as language maintenance centers, and language development centers that expand language domains and oral language abilities, as well as literacy skills. These ideas will be further examined in the following school curriculum discussion.

\section{Discussion of School Curriculum}

As observed before, only one aspect of the FVFP curriculum was written: the general program's aims. I examined that other curricular aspects were present in coordinators' and teachers' discourse. These aspects were organized and analyzed previously in Chapter 4. In order to help the school establish its curriculum development process and make further improvements about it, I organized the current school's curriculum in a basic structure (Table 4). 
Table 4

HL community-based school curriculum current state and recommendations

\begin{tabular}{|c|c|c|c|}
\hline & Description & & Recommendations \\
\hline $\begin{array}{l}\text { The school general } \\
\text { program's aims }\end{array}$ & $\begin{array}{l}\text { The needs that a HL } \\
\text { community-based } \\
\text { school aims to } \\
\text { address for its } \\
\text { students and its } \\
\text { community. }\end{array}$ & $\begin{array}{l}\text { To develop } \\
\text { linguistic and } \\
\text { cultural belonging } \\
\text { in an HL; } \\
\text { To maintain } \\
\text { student's oral HL } \\
\text { abilities; } \\
\text { To enhance } \\
\text { children's pride of } \\
\text { speaking other } \\
\text { language than } \\
\text { English at home; } \\
\text { To make parents } \\
\text { aware of family's } \\
\text { crucial role raising a } \\
\text { bilingual child. }\end{array}$ & $\begin{array}{l}\text { To discuss language } \\
\text { maintenance, and } \\
\text { language } \\
\text { development for its } \\
\text { students. }\end{array}$ \\
\hline $\begin{array}{l}\text { The school } \\
\text { philosophy of } \\
\text { education and } \\
\text { fundamental } \\
\text { educational } \\
\text { concepts. }\end{array}$ & $\begin{array}{l}\text { The fundamental } \\
\text { concepts and ideas } \\
\text { valued as driven } \\
\text { forces in order to } \\
\text { shape teacher- } \\
\text { students } \\
\text { interactions, class } \\
\text { preparations, and } \\
\text { evaluation. }\end{array}$ & & $\begin{array}{l}\text { I recommend that } \\
\text { coordinators and } \\
\text { teachers discuss } \\
\text { ideas about: } \\
\text { - } \text { schooling, } \\
\text { evaluation, } \\
\text { and teaching- } \\
\text { and-learning } \\
\text { - language, its } \\
\text { different } \\
\text { grammars, } \\
\text { different } \\
\text { language } \\
\text { domains, and } \\
\text { different } \\
\text { language } \\
\text { registers } \\
\text { literacy and } \\
\text { its strategies. }\end{array}$ \\
\hline $\begin{array}{l}\text { The school } \\
\text { curriculum goals }\end{array}$ & $\begin{array}{l}\text { The abilities, } \\
\text { competences, and } \\
\text { values that the }\end{array}$ & $\begin{array}{l}\text { General } \\
\text { expectations of } \\
\text { maintaining }\end{array}$ & $\begin{array}{l}\text { The school needs to } \\
\text { establish specific } \\
\text { students' outcomes }\end{array}$ \\
\hline
\end{tabular}




\begin{tabular}{|c|c|c|c|}
\hline & $\begin{array}{l}\text { school understands } \\
\text { as important to } \\
\text { cherish in their } \\
\text { students. }\end{array}$ & $\begin{array}{l}\text { students' language } \\
\text { abilities, and } \\
\text { developing cultural } \\
\text { knowledge. }\end{array}$ & $\begin{array}{l}\text { expected over the } \\
\text { time and relate them } \\
\text { in increasing degrees } \\
\text { of complexity. }\end{array}$ \\
\hline $\begin{array}{l}\text { The subject matter } \\
\text { valued by the } \\
\text { school }\end{array}$ & $\begin{array}{l}\text { The knowledge and } \\
\text { their themes that the } \\
\text { school selected. }\end{array}$ & $\begin{array}{l}\text { Based on themes } \\
\text { such as HL folklore, } \\
\text { Brazilian culture, } \\
\text { the native } \\
\text { Brazilians, the } \\
\text { geographical and } \\
\text { cultural regional } \\
\text { differences, the } \\
\text { typical foods, and } \\
\text { the popular } \\
\text { Brazilians holidays } \\
\text { and festivals, such } \\
\text { as Carnaval and } \\
\text { Festa Junina. }\end{array}$ & \\
\hline $\begin{array}{l}\text { The instructional } \\
\text { strategies valued by } \\
\text { the school }\end{array}$ & $\begin{array}{l}\text { The methods for } \\
\text { class preparation } \\
\text { and evaluation } \\
\text { chosen by the } \\
\text { school workers. }\end{array}$ & $\begin{array}{l}\text { Task-based } \\
\text { approach. }\end{array}$ & $\begin{array}{l}\text { Need further } \\
\text { discussion of the } \\
\text { relation between } \\
\text { comprehension and } \\
\text { teaching and } \\
\text { learning. }\end{array}$ \\
\hline
\end{tabular}

One great aspect of the South Florida program studied was that coordinators and teachers have been using a task-based approach to engage and motivate students during classes. Additionally, the students' motivation can be linked to the aim of creating playful and recreational lessons, teachers' previous educational experiences, and teachers not working as volunteers at FVFP. However, some recommendations can help the school further develop its curriculum in order to enhance class preparation and students outcomes. 


\section{Recommendations for a Curriculum Development Process}

As the previous table showed, despite the great characteristics of the HL community-based school studied, some recommendations can be made to improve its curriculum and instruction development. A lack of formal education related specifically to HL teaching and learning, as well as curriculum development can explain some contradictions and misconceptions presented by teachers and coordinators. Consequently, the program will benefit from teacher training courses and further curriculum discussion. At FVFP this debate can focus specifically on curriculum aspects such as fundamental concepts for HL education, the school curriculum goals, and the instructional strategies selected.

\section{The fundamental concepts for HL education.}

Although the teachers and the coordinators have consistently been communicating during the semester, it seems that they have been discussing practical issues.

Consequently, less attention was dedicated to discussing main educational concepts. This situation is explained by the lack of teachers' and coordinators' background knowledge about issues specifically important at HL community-based schools, such as bilingualism, bilingual language acquisition, and developing a curriculum that address HLLs needs. I will examine each of these aspects and relate them with the ideas previously explored in Chapter II. 


\section{School.}

Teachers and coordinators interviewed in this research refused to use the term school in order to classify their program because they only provide 1-hour-activity per week, and do not grade or use measurement tests to evaluate their students. However, the Oxford Dictionary of Education defines school as "an institution in which pupils are taught" (Wallace, 2008, p. 258). In my understanding, the FVFP's activities can be classified as school. The children are participating in learning experiences there, and beyond the classes, the stakeholders act intensively to educate parents, and support families to establish strategies to maintain students' bilingualism at home.

Although with limited hours per week, they can be named as a school that aims maintain and develop student cultural and language abilities. Based on frequency of instruction, Fishman (2001) observed that in the U.S. there are different types of HL schools such as all-day schools, weekday afternoon schools, weekend schools, schools offering summer programs, evening classes, and special classes in community centers.

Historically, ethnic groups established these centers to support language maintenance, as well to develop cultural knowledge in a HL (Liu, 2010). As Liu observed, principal, teachers, and parents involved in these programs firmly believe that the main role of a HL school is to teach language and culture to their students:

While they recognize that their children would not become fully proficient in their heritage language by studying it two hours per week, they believed that the school at least provided an environment for children to learn the language systematically and made learning the language parte of a routine. (Liu, 2010, p. 1) 
Based on these ideas, I recommend that FVFP review its important function as a school that acts as a valuable resource for Brazilian families in South Florida. Furthermore, the program needs to discuss implications of being a school and holding teaching-learning activities.

\section{Bilingualism.}

In my understanding, it is important that the FVFP teachers and coordinators start to challenge the predominant idea of a bilingual person as one who presents two monolingual proficiencies in one. This study considered François Grosjean's (2010) definition as bilinguals "those who use two or more languages (or dialects) in their everyday lives" (Grosjean, 2010, p. 4). In the context of HLLs, it is important to understand bilingualism as a continuum and dynamic condition, when one will demonstrate strengths in different contexts and domains over the course of a lifetime (Lynch, 2003). If teachers only value the students' achievements in standardized grammar proficiency, they will be devaluing the HLLs who use specific language registers and domains efficiently (Valdés, 1995).

At FVFP, teachers affirmed seeing prejudice against the students possessing a marked foreign speech accent. This issue is related to the fear that students visiting Brazil will face preconceptions from the extended family, which hold expectations that these children speak fluently and with no accent, differing from a foreign language learner. Parodi (2009) described a similar situation of negative attitudes toward Spanish HLLs visiting Latin American countries. 
It is crucial that HL community-based schools work with teachers and families to be aware of the dominant language interference in the HL. Researchers such as Lynch (2003) and Zentella (2003) have discussed how a HL development can be understood as a language in contact development. Based on Silva-Corvalán (1995) observations, Lynch (2003) argued that HLLs can show simplification of grammatical categories and lexical oppositions, overgeneralization of forms, development of periphrastic constructions, direct and indirect transfers of forms across languages, and code-switching.

Considering these ideas, HLLs should be valued by their efforts to improve their language skills in different contexts, rather then be compared with a monolingual native speaker. Besides, these learners cannot extinguish their multiple identities and their multiple everyday language use. As a recommendation, the school needs to discuss what it means to be bilingual, and help families to break down preconceptions and false expectations.

Relating bilingualism and identity, I understand that a valuable idea at FVFP was that teachers and coordinators respect the fact that these children hold multiple identities. This study assumed that minority language students belong to multiple cultures and create multiple identity discourses (Nieto, 2002). Furthermore, in this study language and identity are integrated as fundamental notions of the learner social reality, and rely on Hall and Gay's (1996) idea that identity is a fluid construction that one creates by his owns discourses through the life.

Adjusted to these ideas, at FVFP, teachers see as important to value the bilingual children multiple identities, as well as to help parents to grasp this concept. However, this idea should be more deeply embraced by the school and extended for aspects such as 
language abilities. As Lee and Kim (2008) researched, for HLLs, the language does not simply perform the function of ordinary communication, but it is also a symbolic marker of identity. Consequently, the school will benefit from discussing different concepts of bilinguals in order to understand what ideas adjust to their students' and community's reality, as well as to educate parents and families to prevent learners' discrimination because of their language in contact development.

\section{Language.}

It seems that the participants' understanding of language was related to the standardized grammar, consequently for them, language is learned through repetitive grammatical exercises. This practice, in their view, contradicts the program's instructional goal of offering recreational activities to their students. Comparing the pedagogical needs of HLLs and foreign language students, Kagan and Dillon (2002) concluded that HLLs benefit from a macro-approach grammar. This strategy uses age appropriate oral and written texts to concentrate on grammar concepts and structures rather them focus on nomenclature and decontextualized exercises. The program will gain with the discussion about what a language is, as well as the language different grammars, domains, and registers. HL teachers, therefore, need to debate how to help these learners to develop formal language registers, and how students can be linguistically efficient in different situations.

As another result of this study, I recommend that HL teachers need training courses that discuss these issues as well as language acquisition. These courses need to specifically debate the role of the quality and quantity of input in grammar structure 
acquisition. Gathercole $(2002,2007)$ observed that the amount of exposure affects timing of bilingual development, and it is related to a critical mass amount of data needed before a child discover a general language pattern. Considering that an early bilingual child is hearing input from different languages, in different contexts, Gathercole concluded that it "takes the bilingual child a little longer to develop those structures because of the need for the accumulation of enough data in order to draw out the relevant abstractions from the raw data supplied in the input" (Gathercole, 2007, p. 17).

Paradis noted that for early bilinguals "input quality might be an equal, or perhaps more relevant, factor" (Paradis, 2011, p. 668). The researcher referred as input quality the differences in exposure; proficiency of interlocutors; and complexity of contact experienced via media, playmates, and organized extra-curricular activities. In my understanding, HL community-based schools can play a great effective role for its students in offering quality of input in order to consolidate students' grammar structures.

\section{Literacy.}

As observed before, at FVFP all teachers described to use literacy activities for students five years and older; however, they refused to name their practices as literacy. Furthermore, all the coordinators declared expectations for students learning or improving reading and writing abilities at the program. One possible explanation for this contradiction is that there is no consistent understanding about what is literacy among participants.

It is common that HL competence refers to the casual and conversational speech register used with familiar interlocutors and restricted to a set of topics focused on 
everyday life (Valdés, 1995). Discussing HLLs needs, Valdés (1997) concluded that HLLs' literacy is considered a key issue that should be developed during a lifetime period. The HL community-based schools' curriculum should be designed to expand the functional domain of the family oral language register to oral formal registers, as well as written informal and formal registers.

In my understanding, at HL community-based schools, literacy must be related to social practices and cultures, and children should be active participants in their own language and literacy development (Ferreiro, 2010). The target of literacy at HL community-based schools should build writers' and readers' awareness of texts' social contexts. This idea means that students need to produce and read texts awareness of who

is the interlocutor, what is the purpose of the text, what is the appropriated language register to use, and what are texts common structure.

Colombi and Roca (2003) described that Spanish HL teachers that explicitly approach how language registers functions in different social contexts, have helped HLLs become more aware of appropriate lexical-grammatical features making their writing more effective. This research is based on the idea that literacy teachers can have a critical role in mediating children to construct their own experiences with texts.

A fundamental way to improve program's effectiveness on language development is teachers and coordinators developing knowledge about literacy and its strategies. Related to this, the participants also showed little knowledge about how mainstream schools develop literacy in the U.S. Consequently, other ways of improving HL community-based schools' practices involves $\mathrm{Hl}$ teachers awareness of how these 
children are being literate at the mainstream school. Additionally, HL schools also will benefit from knowledge about how bilingual children transfer their literacy skills to other languages learned simultaneously. Doing so, teachers and coordinators can establish a deeper discussion about their curriculum goals and their instructional strategies.

\section{The school curriculum goals.}

As observed before, the idea of establishing curriculum goals is important for elucidating the expectations that a school holds for its students. As Posner (2004) described, these goals set the characteristics that are supposed to result from learning over the years and across the subject matter of schooling. These goals usually represent values, knowledge, and attitudes that a school respects and expects that students will learn and develop during the time.

At FVFP, it was not clear for teachers and coordinators what the program expects that their students accomplish by the end of the year. The interviewees only stated some general goals for their students such as maintaining HLLs' oral abilities and developing cultural knowledge. These goals were not established in a time line or with increasing degrees of complexity, or even considering how to expand their language abilities.

The curriculum goals usually describe the students' performance that all the school's personnel are engaged in helping them to achieve. Usually they are stated by the school as "at this school students will be able to", or "they will demonstrate, learn, appreciate, develop" (Oliva, 2009, p. 224) and so on.

In my understanding, the program and specifically the teachers will benefit from establishing goals for its students in order to prepare their lessons more conscientiously. 
The curriculum goals are especially important in order to challenge teachers to prepare classes focusing on the desired learning. As Wiggins and McTighe (2005) suggest, "lessons, units, and courses should be logically inferred from the results sought, not derived from the methods, books, and activities with which we are most comfortable" (Wiggins and McTighe, 2005, p.14).

At FVFP, the absence of students' learning expectations leads to the lack of students' outcomes assessment. As Wiggins and McTighe (2005) observed, to assess can be understood as to analyze students' accomplishment against specific goals using some criteria. I recommend that the HL school establishes more specific curriculum goals and a continuous assessment process in order to check student's understanding of cultural knowledge, as well as of their language performances. As Wiggins and McTighe (2005) observed, the assessment needs to be thought as a collection of evidence over the time:

This continuum assessments includes checks of understating (such as oral questions, observations, dialogues); traditional quizzes, tests, and open-ended prompts; and performance tasks and projects. They vary in terms of scope (from simple to complex), time frame (from short- to long-term), setting (from decontextualized to authentic contexts), and structure (from highly directive to unstructured). Wiggins and McTighe (2005, p. 152)

At FVFP teachers and coordinators view cultural knowledge as capable of creating the disposition of belonging to a HL. However, this idea does not recognize the internal aspects of humans, such as motivation, how the family values and acts to 
embrace their multiple identities (Posner, 2004), or even how the local ethnic community influences students' engagement in a HL. More research is needed to understating how these factors affect students' engagement in a point to create belonging in a HL.

\section{The instructional strategies.}

As instructional strategy, the FVFP uses a task-based approach in order to advance the motivation of students in their learning experiences during the classes. In this method, teachers create an environment that targets learning the language itself, but the style of the instruction places emphasis on interactions using conversation and tasks requiring language use. A great aspect of this instructional strategy can be to expose learners to a variety of language use contexts and situations (Lightbown and Spada, 2006).

However, not all the participants in this study understood that language is learned through the tasks founded on cultural contents. The misunderstanding is based on some teachers' and coordinators' idea that language is a secondary lesson goal.

What we can draw for the HL community-based school experience is that language and culture are the main goal of the classes. It seems that the school needs to further discuss its content-based curriculum and instructional strategies in order for all teachers and coordinators to grasp the idea of what are the goals of a task-based approach.

At FVFP, an interesting idea emerged when teachers and coordinators described how they organize their instruction: an opposition between comprehending and playing. They described separating the learning and comprehension part from the hands-on 
activities part: 30 minutes of "content", or "traditional teaching", and 30 minutes of "recreational activities".

This study considers Ruddel and Unrau's (1994) understanding that during the classes, meaning is a complex and dynamic result of all the interactions among texts, teachers, readers, classroom context, and sociocultural context. Ruddel and Unrau also extended the meaning process beyond printed manuscripts but to events, speech, and behaviors as readers can interpret gestures, images, symbols, signs and signals embedded in a social and cultural environment.

As a positive aspect of FVFP, the task-based approach is valued by research (e.g., $\mathrm{Wu}, 2008$ ) indicating that a content-based curriculum is more effective for HLLs because such practices foster respect for the students' previous language skills. However, the school needs to further discuss that through hands-on activities students are using comprehension, developing language skills, and learning cultural knowledge. It is important to break down some misconceptions and to understand that students are learning and comprehending all the time at school, as well as through hands-on activities.

\section{Conclusion}

Schools simultaneously represent and shape the needs of the society. Therefore, directors, coordinators, teachers, parents, and students create expectations about how these institutions contribute to accomplish goals related to students and community needs (Posner, 2004). This study looked for the teachers' and coordinators' perception of a Brazilian-Portuguese HL community-based school's roles and curriculum development in South Florida. Further research is needed to understand family and student perceptions of 
the curriculum, as well as their motivation in order to enroll at Brazilian HL communitybased schools.

This research was aimed at describing, understanding, and discussing the curriculum development process of a community-based school and make further recommendations that are hopefully valid for other centers in the U.S. As Rivera-Mills (2012) highlighted, there is a need to integrate the recent research into teacher training programs, material design, and curriculum planning for HL community-based schools.

Taking into account the Brazilian program studied, I recommend that teachers training courses for HL community-based schools involve core issues such as the following:

- what a language is: the language different grammars, domains, and registers; bilingual language acquisition, specifically discussion of the role of quality and quantity of input; and what is understood as language maintenance and language development at these schools;

- what literacy is: literacy strategies, how bilingual children transfer their literacy skills to other languages learned simultaneously, and how these children are being literate at the mainstream school;

- what bilingualism is: a discussion of different definitions of what it means to be a bilingual person, language interference in early bilinguals, and how bilingual children transfer their literacy skills to other languages learned simultaneously. 
- curriculum development: how to recognize the needs of HLLs in a specific community; how to establish curriculum goals; how to select and discuss instructional strategies; how to select subject matter.

These findings hopefully might help the Brazilian HL community schools toward discussing and elaborating their own curriculum development process by considering their specific contexts and needs. Furthermore, these research findings hopefully can contribute to Florida universities trying to develop HL teacher training courses. National programs, such as the Center for Applied Linguistics, the National Foreign Language Center, and universities, such as the University of Maryland and UCLA have been offering sporadic courses and seminars. Hopefully, Florida's heritage communities will develop partnerships with universities in order to improve their effectiveness as centers that maintain and develop children's bilingual abilities. 


\section{LIST OF REFERENCES}

Baker, C. (2001). Foundations of bilingual education and bilingualism ( $5^{\text {th }}$.ed.).

Clevedon, England: Multilingual Matters.

Br. Ministério das Relações Exteriores. [Ministry of Foreign Relationship]. (2011)

Brasileiros no mundo 2010: Estimativas. Brasília, DF. Retrieved on January 20, 2014, from http://www.brasileirosnomundo.itamaraty.gov.br/acomunidade/estimativas-populacionais-dascomunidades/Brasileiros\%20no\%20Mundo\%202011\%20-\%20Estimativas\%20$\% 20$ Terceira\%20Edicao\%20-\%20v2.pdf

Bialystok, E. (2007). Cognitive effects of bilingualism: How linguistic experience leads to cognitive change. International Journal of Bilingual Education and Bilingualism, 10(3), 210-223.

Bourdieu, P. (2005). A economia das trocas simbólicas. [The economy of symbolic goods] (6a. ed.). São Paulo, Brazil: Perspectiva.

Carreira, M., \& Kagan, O. (2011). The results of the national heritage language survey: Implications for teaching, curriculum design, and professional development. Foreign Language Annals, 44, 40-64. doi: 10.1111/j.1944-9720.2010.01118.x

Colombi, M.C \& Roca, A. (2003). Insights from research and practice in Spanish as a heritage language. In A. Roca \& M. C. Colombi (Eds.), Mi lengua: Spanish as a heritage language in the United States (pp. 1-21). Washington DC: Georgetown University Press.

Compton, C. J. (2001). Heritage language communities and schools: Challenges and recommendations. In J. K. Peyton, D. A. Ranard, \& S. McGinnis (Eds.), Heritage languages in America: Preserving a national resource (pp. 145-166). Washington, DC: Center for Applied Linguistics and Delta Systems.

Douglas, M. O. (2008). Curriculum Design for Young Learners of Japanese as a Heritage Language. In K. Kondo-Brown \& J. D. Brown. (Eds.), Teaching Chinese, Japanese, and Korean Heritage Language Students (pp. 237-298). New York, NY: Lawrence Erlbaum Associates.

Duff, P. (2008). Heritage language education in Canada. In D. Brinton, O. Kagan \& S. Bauckus (Eds.), Heritage language: A new field emerging (pp. 71-90). New York: Taylor \& Francis.

Ferreiro, E. (2010). Reflexões sobre alfabetização. [Reflexions about literacy]. São Paulo: Cortez. 
Almeida Filho, J. P. (2008). Tornar-se professor de língua(s) na estrangeiridade domada. [Becoming a foreign language(s) teacher in a tamed forein relationship]. São Paulo: Pontes.

Fishman, J. (2001). 300-plus years of heritage language education in the United States. In J. K. Peyton, D. A. Ranard, \& S. McGinnis (Eds.), Heritage languages in America: Preserving a national resource (pp. 81-89). DC: Center for Applied Linguistics \& Delta Systems.

Fundação Vamos Falar Português (2012). Sobre a VFP. [website] Retrieved on June 10, 2014, from http://www.vamosfalarportugues.org/index.php?option=com_content\&view=artic le\&id $=14 \&$ Itemid $=2 \&$ lang $=\mathrm{pt}$

García, O.; Zakharia, Z. \& Otcu, B. (2013). Bilingual Community Education for American Children: Beyond Heritage Languages in a Global City. Bristol, UK: Multilingual Matters.

Gathercole, V. C. (2002). Monolingual and bilingual acquisition: Learning different treatments of that-trace phenomena in English and Spanish. In D. K. Oller \& R. E. Eilers (Eds.), Language and literacy in bilingual children (p.1-32) Clevedon, UK: Multilingual Matters.

Gathercole, V. C. (2007). Miami and North Wales, so far and yet so near: A constructivist account of morphosyntatic development in bilingual children. The International Journal of Bilingual Education and Bilingualism, 10(3), 1-24.

Gathercole, V. C., \& Thomas, E. M. (2009). Bilingual first-language development: Dominant language takeover, threatened minority language takeup. Bilingualism: Language and cognition, 12(2), 213-237.

Grosjean, F. (2010). Bilingual: Life and reality. Cambridge, MA: Harvard University Press.

Hall, S. \& Gay, P. (1996). Questions of cultural identity. London, UK: Sage.

He, A. W. (2008). Chinese as a heritage language: An introduction. In A.W. He \& Y. Xiao (Eds.), Chinese as a heritage language: Fostering rooted world citizenry (pp. 1-12). Mānoa, HI: National Foreign Language Resource Center, University of Hawai'i at Mānoa.

Hornberger, N. H. \&Wang, S. C. (2009). Who are our heritage language leaners? Identity and biliteracy in heritage language education in the United States. In D. M. Brinton, O. Kagan, \& S. Bauckus (Eds.), Heritage language education: A new field emerging (p.3-35). New York: Taylor \& Francis Group. 
Hyland, K. (2002). Genre: language, context and literacy. Annual Review of Applied Linguistics. 22, 113-135. doi: 10.1017/S0267190502000065

Jouët-Pastré, C. (2011). Mapping the world of the heritage language learners of Portuguese: Results from a national survey at the college level. Portuguese Language Journal. 5, Fall, 2011. Retrieved on September 03, 2014, from http://www.ensinoportugues.org/current-articles/.

Kagan, O. \& Dillon, K. (2012) Heritage languages and L2 learning, In S. Guss \& A. Macke (Eds.), The Routledge Handbook of Second Language Acquisition (pp. 491-505). London, UK: Routledge.

Kelleher, A. (2010). What is a heritage language? In Heritage Briefs. Retrieved on April 1, 2013, from http://www.cal.org/heritage/pdfs/briefs/What-is-a-HeritageLanguage.pdf

LaFromboise, T., Coleman, H., and Gerton, J. (1993) Psychological impact of biculturalism: Evidence and theory. Psychological Bulletin, 114 (3), 395-412.

Lee, J. S., and Kim, H. (2008). Heritage language learners' attitudes, motivations, and instructional needs: The case of postsecondary Korean language learners. In K. Kondo-Brown \& J. D. Brown (Eds.), Teaching Chinese, Japanese, and Korean heritage language students: Curriculum needs, materials, and assessment (pp. 159-186). New York, NY: Lawrence Erlbaum Associates.

Li, D., \& Duff, P. (2008). Issues in Chinese heritage language education and research at the postsecondary level. In A. W. He \& Y. Xiao (Eds.), Chinese as a heritage language: Fostering rooted world citizenry. Honolulu, HI: National Foreign Language Resource Center.

Li, M. (2005). The role of parents in Chinese heritage-language schools. Bilingual Research Journal: The Journal of the National Association for Bilingual Education, 29:1, 197-207, DOI: 10.1080/15235882.2005.10162831

Lico, A. L. (2011). Educação e cultura brasileira para falantes de herança na região de VA, MD e DC. Portuguese Language Journal,5, Fall, retrieved on March, 2014, http://www.ensinoportugues.org/wp-content/uploads/2011/05/Lico.pdf

Lightbown, P. M., Spada, N. (2006). How languages are learned ( $3^{\text {rd }}$. ed). New York, NY: Oxford University Press.

Lynch, A. (2003). Toward a theory of heritage language acquisition. In A. Roca \& M.C. Colombi (Eds.), Mi lengua: Spanish as a heritage language in the United States (pp. 25- 50). Washington, DC: Georgetown University Press. 
Liu, N. (2010). The role of Heritage Language Schools in Building a Multilingual Society. Heritage Briefs Collection, retrieved on April 1, 2013, from http://www.cal.org/heritage/pdfs/briefs/the-role-of-heritage-language-schools.pdf

Liu, N., Musica, A., Koscak, S., Vinogradova, P., \& Lòpez, J. (2011). Challenges and needs of community-based heritage language programs and how they are addressed. Heritage Briefs Collection. Retrieved on April 1, 2013, from http://www.cal.org/heritage/pdfs/briefs/challenges-and\%20needs-of-communitybased-heritage-language-programs.pdf

Liu, P. (2006) Community-based Chinese schools in Southern California: A Survey of teachers, Language, Culture and Curriculum, 19:2, 237-247, doi:10.1080/07908310608668765

Lu, X. (2001). Bicultural identity development and Chinese community formation: An Ethnographic study of Chinese schools in Chicago, Howard Journal of Communications, 12:4, 203-220, doi: 10.1080/106461701753287723

McGinnis, S. (2005). From mirror to compass: The Chinese heritage language education sector in the United States. In D. M. Brinton, O. Kagan, \& S. Bauckus, (Eds.), Heritage language education: A new field emerging (pp. 229-242). New York, NY: Taylor \& Francis Group.

McInerny, P. (2013). "Community language schools: A rich and diverse resource flying under the radar." UCLA International Institute. Retrieved on April, 22, 2013, from http://www.international.ucla.edu/cmed/article/131536

Merriam, S.B. (2009). Qualitative research: A guide to design and implementation. (2 ${ }^{\text {nd }}$ ed.) San Francisco, CA: Jossey-Bass.

Morgan, D. L. (1997). Focus groups as qualitative research $\left(2^{\text {nd }}\right.$. Ed.). Thousand Oaks, CA: SAGE.

Newman, M. (2006). Definitions of literacy and their consequences. In H. Luria, D. M. Seymour \& T. Smoke (Eds.), Language and Linguistics in Context: Readings and Applications for Teachers (p243-254). New Jersey, NJ: Lawrence Erlbaum.

Nieto, S. (2002). Language, culture, and teaching: Critical perspectives for a new century. Mahwah, NJ: Lawrence Erlbaum Association.

O'Grady, W., Kwak, H., Lee, M., \& Lee, O. (2011). An emergentist perspective on heritage language acquisition. Studies in second language acquisition, 33, 223245. doi:10.1017/S0272263110000744 
Oliva, P. F. (2009). Developing the curriculum (7th ed.). Boston, MA: Allyn \& Bacon.

Paradis, J. (2010). Bilingual children's acquisition of English verb-morphology: Effects of language exposure, structure complexity, and task type. Language Learning, 60(3), pp. 651-680.

Paradis, J., Nicoladis, E. Crago M. \& Genesee, F. (2010). Bilingual children's acquisition of the past tense a usage-based approach. Journal Children Language, 37(25). doi:10.1017/S0272263110000744

Paradis, J. (2011). Individual differences in child English second language acquisition: comparing child-internal and child-external factors. Linguistic Approaches to Bilingualism, 1(3), 213-238, doi 10.107/lab.1.3.01par

Parodi, C. (2006). Stigmatized Spanish inside the classroom and out: A Model of language teaching to heritage speakers. In Brinton, D. M., Kagan, O., \& Bauckus, S. (Eds.), Heritage language education: A new field emerging (p.3-35). New York, NY: Taylor \& Francis Group.

Peyton, J. K., Ranard, D. A., \& McGinnis, S. (2001). Heritage languages in America: Preserving a national resource. Washington, DC: Center for Applied Linguistics \& Delta Systems.

Posner, G. J. (2004). Analyzing the curriculum. ( $3^{\text {rd }}$ ed). New York, NY: McGraw-Hill.

Potowski, K. (2012). Identity and heritage learners: Moving beyond essentializations. In S. M. Beaudriw \& M. Fairclough (Eds.), Spanish as a heritage language in the United States: The state of the field (p.179-199). Washington, DC: Georgetown University Press.

Rivera-Mills, S. V. (2012). Spanish heritage language maintenance: Its Legacy and its future. S. M. Beaudrie \& M. Fairclough (Eds.), Spanish as a Heritage Language in United States (pp. 21-42). Washington, D.C.: Georgetown University Press.

Seidman, I. (1998). Interviewing as qualitative research: A guide for researchers in education and the social sciences ( $4^{\text {th }}$ ed.). New York, NY: Teachers College Press.

Shibata, S. (2000). Opening a Japanese Saturday school in a small town in the United States: Community collaboration to teach Japanese as a heritage language. Bilingual Research Journal, 24(4), 465-74. 
Silva, G.V. (2010). On starting a course sequence for heritage learners of Portuguese. Portuguese Language Journal, 4, Fall. Retrieved from http://www.ensinoportugues.org/archives/

Thomas, W. P. and Collier, V. P. (1997). School effectiveness for language minority students. Washington, DC: National Clearinghouse for Bilingual Education.

Ruddell, R. B., \& Unrau, N. J. (2004). Theoretical models and processes of reading (5 ${ }^{\text {th }}$ ed.). Newark, DE: International Reading Association.

Santa Ana, O., \& Parodi, C. (1998). Modeling the speech community: Configurations and variable types in the Mexican Spanish setting. Language in Society, 27, 23-52.

U.S., U.S. Census Bureau (2010). Kominski, R. A., \& Shin, H. B. Language in use in United States: 2007. Retrieved on April 19, 2013, from

http://www.census.gov/prod/2010pubs/acs-12.pdf

U.S., U.S. Census Bureau (2013). Ryan, C. Language use in the United States: 2011. American Community survey reports. Retrieved on January 20, 2014, from https://www.census.gov/content/dam/Census/library/publications/2013/acs/acs$\underline{22 . p d f}$

Valdés, Guadalupe. (1997). The teaching of Spanish to bilingual Spanish-speaking students: Outstanding issues and unanswered questions. In M. C. Colombi \& F. X. Alarcón (Eds), La enseñanza del español a hispanohablantes: praxis y teoría (pp.8-44). Boston, MA: Houghton Mifflin.

Valdés, G. (1995). The teaching of minority languages as academic subjects:

Pedagogical and theoretical challenges. The Modern Language Journal, 79(3), 299-328.

Valdés, G. (2001). Heritage language students: Profiles and possibilities. In J. K. Peyton, D. A. Ranard \& S. MacGinnis (Eds.), Heritage languages in America: Preserving a national resource (pp.37-77). Washington, DC: Center for Applied Linguistics/Delta Systems.

Wallace, S. (2008). Oxford dictionary of education. New York, NY: Oxford University Press.

Wiggins, G. \& McTighe, J. (2005). Understanding by design $\left(2^{\text {nd }}\right.$. Ed). New Jersey, NJ: Pearson Education. 
Wiley, T. G. (2001). On defining heritage languages and their speakers. In J. K. Peyton, J. K., D. A. Ranard \& S. McGinnis (Eds.), Heritage languages in America:

Preserving a national resource (pp. 29-36). Washington, DC: Center for Applied Linguistics \& Delta Systems.

Wiley, T. (2014). The problem of defining heritage and community languages and their speakers: On the utility and limitations of definitional constructs. In T. Wiley, J. Peyton, D. Christian, S. Moore\& N. Liu (2014). Handbook of Heritage, community, and Native American languages in the United States: research, policy, and educational practices (pp. 19-34). Washington DC: CAL/ Routledge.

Wong, S. C., \& Lopez, M. G. (2000). English language learners of Chinese background. In S. L. McKay \& S. C. Wong (Eds.), New immigrants in the United States (pp. 263-305). Cambridge, MA: Cambridge University Press.

Wu, S. (2008). Robust learning for Chinese heritage leaners: Motivation, linguistics and Technology. In K. Kondo-Brown \& J. D. Brown (Eds.), Teaching Chinese, Japanese, and Korean Heritage Language Students (pp. 271-298). New York, NY: Lawrence Erlbaum Associates.

You, B., Liu, N. (2011). Stakeholders views on the roles, challenges, and future prospects of Korean and Chinese heritage language-community schools in the Phoenix Metropolitan Area: A comparative study. Heritage Language Journal, 8(3):67-92.

Zentella, A. C. (2006). Hablamos Spanish and English. In H. Luria, H.; D. M. Seymour \& T. Smoke (Eds.), Language and linguistics in context: Readings and applications for teachers (pp.85-88). New Jersey: Lawrence Erlbaum Associates. 


\section{APPENDICES}

Appendix A: Adult Consent 


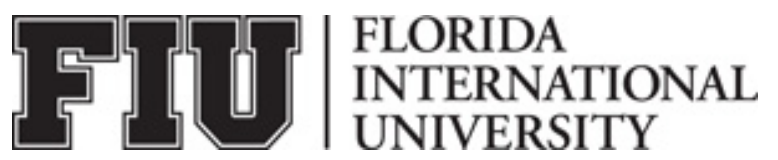

ADULT CONSENT TO PARTICIPATE IN THE RESEARCH STUDY:

HERITAGE LANGUAGE COMMUNITY-SCHOOL'S CURRICULUM

DEVELOPMENT PROCESS: A QUALITATIVE RESEARCH ABOUT A

BRAZILIAN-PORTUGUESE PROGRAM IN SOUTH FLORIDA

\section{PURPOSE OF THE STUDY}

You are being asked to be in a research study. The purpose of this study is to describe, understand, and discuss the curriculum development process of a heritage language community-school.

\section{NUMBER OF STUDY PARTICIPANTS}

If you decide to be in this study, you will be one of 4 people in this research study.

\section{DURATION OF THE STUDY}

Your participation will require a total of 3 hours. The research will visit the communityschool 2 times after Saturdays' classes on April and May, 2014 to ask you to engage in interviews and to observe you teaching at this school.

\section{PROCEDURES}

If you agree to be in the study, we will ask you to do the following things: 
1. To allow the research observe your selected classes' activities. During this time the researcher will take notes about the activities' purposes, abilities and continents.

2. To answer questions participating in an audio taping interview related to curriculum development process such as community-school goals, instructional goals, how you prepare your classes activities, and how you evaluate your students' language development.

3. To share documents and notes that can describe your curriculum development process.

\section{RISKS AND/OR DISCOMFORTS}

There is no risk associated with your participation in this study.

\section{BENEFITS}

It is expected that this study will benefit society by

- establishing further recommendations in curriculum design considering the heritage language teachers and students specific needs;

- assisting heritage language community-schools to critically reflect about their pedagogical practices;

- and, discussing the relevant issues for future heritage language teacher's training courses.

\section{ALTERNATIVES}


There are no known alternatives available to you other than not taking part in this study. However, any significant new findings developed during the course of the research which may relate to your willingness to continue participation will be provided to you.

\section{CONFIDENTIALITY}

The records of this study will be kept private and will be protected to the fullest extent provided by law. In any sort of report we might publish, we will not include any information that will make it possible to identify a subject. Research records will be stored securely and only the researcher team will have access to the records. However, your records may be reviewed for audit purposes by authorized University or other agents who will be bound by the same provisions of confidentiality.

\section{COMPENSATION \& COSTS}

You will not receive a payment for your participation, and you will not be responsible for any costs to participate in this study.

\section{RIGHT TO DECLINE OR WITHDRAW}

Your participation in this study is voluntary. You are free to participate in the study or withdraw your consent at any time during the study. Your withdrawal or lack of participation will not affect any benefits to which you are otherwise entitled. The investigator reserves the right to remove you without your consent at such time that they feel it is in the best interest. 


\section{RESEARCHER CONTACT INFORMATION}

If you have any questions about the purpose, procedures, or any other issues relating to this research study you may contact Ivian Destro Boruchowski at telephone: 305-3011874, and email: idest001@fiu.edu or idestro@yahoo.com.br.

\section{IRB CONTACT INFORMATION}

If you would like to talk with someone about your rights of being a subject in this research study or about ethical issues with this research study, you may contact the FIU Office of Research Integrity by phone at 305-348-2494 or by email at ori@fiu.edu.

\section{PARTICIPANT AGREEMENT}

I have read the information in this consent form and agree to participate in this study. I have had a chance to ask any questions I have about this study, and they have been answered for me. I understand that I am entitled to a copy of this form after it has been read and signed.

Signature of Participant

Printed Name of Participant

Signature of Person Obtaining Consent
Date

Date 
Appendix B: Informational Letter 


\section{FLORIDA INTERNATIONAL UNIVERSITY}

INFORMATIONAL LETTER

\section{HERITAGE LANGUAGE COMMUNITY-SCHOOL'S CURRICULUM DEVELOPMENT PROCESS: A QUALITATIVE RESEARCH ABOUT A BRAZILIAN-PORTUGUESE PROGRAM IN SOUTH FLORIDA}

Hello, my name is Ivian Destro Boruchowski. You have been chosen at random to be in a research study about heritage language community-schools' curriculum development. The purpose of this study is to describe, understand, and discuss the curriculum development process of a heritage language community-school. If you decide to be in this study, you will be one of 4 people in this research study. Participation in this study will take 3 hours of your time. If you agree to be in the study, I will ask you to do the following things:

4. To allow the research observe your selected classes' activities.

5. To answer questions participating in a semi-structured interview.

6. To share any documents or notes that can describe your curriculum development process. 
There are no foreseeable risks to you for participating in this study. It is expected that this study will benefit society by

- establishing further recommendations in curriculum design considering the heritage language teachers and students specific needs;

- assisting heritage language community-schools to critically reflect about their pedagogical practices;

- and, discussing the relevant issues for future heritage language teacher's training courses.

There is no cost or payment to you. If you have questions while taking part, please stop me and ask. You will remain anonymous and your answers will be coded to guarantee your confidentiality. If you have questions for the researcher conducting this study, you may contact Ivian Destro Boruchowski at 305-301-1874. If you would like to talk with someone about your rights of being a subject in this research study or about ethical issues with this research study, you may contact the FIU Office of Research Integrity by phone at 305-348-2494 or by email at ori@fiu.edu.

Your participation in this research is voluntary, and you will not be penalized or lose benefits if you refuse to participate or decide to stop. You may keep a copy of this form for your records. 
Appendix C: IRB Research Approval 


\section{MEMORANDUM}

To:

Dr. Eric Dwyer

CC:

File

From:

Donna J. Simonovitch, Coordinator, Research Integrity

P.S.

Date:

April 25, 2014

Protocol Title: Heritage Language community-schools' curriculum development process: A qualitative research about a Brazilian-Portuguese program in South Florida

The Florida International University Office of Research Integrity has reviewed your research study for the use of human subjects via the Exempt Review process.

IRB Protocol Exemption \#: IRB-14-0077 IRB Exemption Date: 04/25/14 TOPAZ Reference \#: 102253

As a requirement of IRB Exemption you are required to:

1) Submit an Event Form and provide immediate notification of:

- Any additions or changes in the procedures involving human subjects.

- Every serious or unusual or unanticipated adverse event as well as problems with the rights or welfare of the human subjects.

2) Submit a Project Completion Report Form when the study is finished or discontinued.

Special
Conditions: N/A

For further information, you may visit the IRB website at http://research.fiu.edu/irb. 